\title{
Ruthenium Complexes as NO Donors for Vascular Relaxation Induction
}

\section{Renata Galvão de Lima ${ }^{1}$, Bruno Rodrigues Silva ${ }^{2}$, Roberto Santana da Silva ${ }^{2}$ and Lusiane Maria Bendhack ${ }^{2, *}$}

1 Faculdade de Ciências Integradas do Pontal, Universidade Federal de Uberlândia, Ituiutaba 38304-402, MG, Brazil; E-Mail: renatagalvao@pontal.ufu.br

2 Departamento de Física e Química, Faculdade de Ciências Farmacêuticas de Ribeirão Preto, Universidade de São Paulo, Ribeirão Preto 14040-903, SP, Brazil;

E-Mails: brunofarmaco@gmail.com (B.R.S.); silva@usp.br (R.S.S.)

* Author to whom correspondence should be addressed; E-Mail: bendhack@usp.br; Tel.: +55-16-3602-4704; Fax: +55-16-3602-4880.

Received: 8 April 2014; in revised form: 9 June 2014 / Accepted: 26 June 2014 /

Published: 7 July 2014

\begin{abstract}
Nitric oxide (NO) donors are substances that can release NO. Vascular relaxation induction is among the several functions of $\mathrm{NO}$, and the administration of $\mathrm{NO}$ donors is a pharmacological alternative to treat hypertension. This review will focus on the physicochemical description of ruthenium-derived NO donor complexes that release NO via reduction and light stimulation. In particular, we will discuss the complexes synthesized by our research group over the last ten years, and we will focus on the vasodilation and arterial pressure control elicited by these complexes. Soluble guanylyl cyclase (sGC) and potassium channels are the main targets of the NO species released from the inorganic compounds. We will consider the importance of the chemical structure of the ruthenium complexes and their vascular effects.
\end{abstract}

Keywords: nitric oxide; ruthenium-derived complexes; vasodilation; blood pressure control; soluble guanylyl cyclase; potassium channels 


\section{Introduction}

Nitric oxide (NO) has become one of the most important intercellular signaling molecules identified in the 1980s. Knowledge about its involvement in all kinds of physiological systems continues to expand. NO plays a role in platelet aggregation inhibition [1]; it also participates in the control of respiration [2], neurotransmission [3,4], hormone release [5], cell death [6], immune response [7], vascular tone [8-10], and blood pressure [11,12].

The formation, role, and mechanism of action of NO have been exhaustively reviewed [13-15]. The conversion of L-arginine to L-citrulline by the enzyme NO synthase (NOS) produces physiological NO. However, it is in the vascular smooth muscle that NO interacts with the ferrous state of the heme prosthetic center of the $\beta_{1}$ subunit of the enzyme soluble guanylyl cyclase (sGC) - it activates sGC and consequently produces cyclic GMP (cGMP). The latter activates the cGMP-dependent kinase protein (GK), diminishing the cytosolic calcium concentration $\left(\left[\mathrm{Ca}^{2+}\right]_{\mathrm{c}}\right)$ in the vascular smooth muscle cells (VSMC). This mechanism reduces the vascular resistance and helps to maintain the blood pressure at normal levels.

NO is a relatively unstable molecule. It is produced at low concentrations and in the blood it is rapidly converted into nitrate and nitrite within $10 \mathrm{~s}$ of its formation [16]. This short half-life seems to be even lower in several cardiovascular diseases such as hypertension, because oxidative stress reduces NO availability. Several experimental hypertension models can simulate the impaired NO production/availability along with other vascular alterations that are typical of endothelial dysfunction [17]. Therefore, NO supplementation seems to be an interesting strategy to compensate for NO loss and could help ensure normal vasodilation and blood pressure control. In this context, some researchers have proposed that NO donor molecules constitute an effective tool to study this messenger. Authors have also suggested evaluating the different pharmacological characteristics of these molecules, to find out how they can impact the therapy of cardiovascular diseases.

Glyceryltrinitrate (GTN), obtained by Ascanio Sobrero in 1847, was one of the first NO donor molecules to be described. GTN is an organic molecule, a nitrate ester of glycerol. Despite its potent vasodilating and hypotensive effects, it causes side effects like headache and tolerance, which has limited its clinical application [18]. The classic nitrovasodilators organic nitrate and nitrite esters, including GTN, amyl nitrite, isosorbide dinitrate, and nicorandil, have long been used to treat cardiovascular diseases [19,20]. Sodium nitroprusside (SNP), an inorganic molecule, is yet another important and extensively studied NO donor. SNP is a metal nitrosyl complex composed of iron, cyanide groups, and a nitro moiety that together form a square bipyramidal complex capable of inducing potent hypotensive effect. Clinicians have employed SNP for decades, even though it releases highly cytotoxic cyanide [21].

At present, the development of exogenous NO donor agents such as ruthenium-derived metal nitrosyl complexes represents a strategy to reduce any possible side effects and cytotoxicity. Indeed, the ruthenium metal displays chemical characteristics that are similar to those of the iron metal present in the enzymes of biological systems [22]. In addition, nitrosyl ruthenium species seem to be good candidates for the treatment of cardiovascular diseases, because they are generally thermodynamically stable and NO-labile upon external stimulation [23]. 
Hence, this review will highlight the cellular mechanisms involved in the vasodilation prompted by NO and their relationship with the chemical structure of some ruthenium-derived complexes synthesized by our group. It will also discuss the chemical characteristics and vascular mechanisms of the classical NO donor SNP as well as other NO donors.

\section{Nitric Oxide and Its Main Vasodilating Mechanism}

\subsection{NO Release and Vascular Biological Target}

The amount and the site of NO release play an important part in the relaxation induced by NO donors. It is well known that NO is little bioavailable in the cellular milieu. The amount and the lifetime of the NO species released from the NO donors determine the pharmacological effects of this molecule. To induce vascular relaxation, the NO released from NO donors or produced by NO-synthases has to bind to the heme-protein sGC located in the cytosol of the vascular smooth muscle cells or activate potassium $\left(\mathrm{K}^{+}\right)$channels directly.

\subsection{Cellular Mechanisms for Vasodilation}

The NO produced by the NO-synthase enzyme isoforms or the NO released by NO donors binds to sGC in the cytosol of the VSMC, to modulate the activity of sGC positively. The latter enzyme converts GTP to cGMP, which activates protein kinase G (GKI $\alpha$ ). Swayze and Braun [24] have shown that GKI $\alpha$ alone is sufficient to activate $\mathrm{K}^{+}$channels (BKCa) in situ following activation of the NO-cGMP signaling pathway. Activation of cGMP-dependent protein kinases induces vascular relaxation because it lowers the cytosolic $\mathrm{Ca}^{2+}$ concentration and promotes $\mathrm{Ca}^{2+}$ desensitization of the actin-myosin contractile system in the VSMC [25]. Furthermore, $\mathrm{NO}$ and $\mathrm{K}^{+}$channels interact directly, which induces hyperpolarization, reduces cytosolic $\mathrm{Ca}^{2+}$ concentration, and improves vasodilation.

\section{Sodium Nitroprusside and Its Effects on Vascular Tone and Arterial Pressure Control}

Sodium nitroprusside ( $\mathrm{SNP}, \mathrm{Na}_{2}\left[\mathrm{Fe}(\mathrm{CN})_{5}(\mathrm{NO})\right] \cdot 2 \mathrm{H}_{2} \mathrm{O}$ ) was chemically characterized in the middle of the 19th century [26]. Its ability to lower the blood pressure has been known since 1929 [27]. SNP has been clinically employed as a hypotensive agent for over five decades [28], although only after the study reported by Furchgott et al. [8] its pharmacological effect has been attributed to ability of NO release. Regardless of $\mathrm{pH}$ and the photolysis wavelength (over a wide range), the aqua-complex $\left[\mathrm{Fe}(\mathrm{CN})_{5} \mathrm{H}_{2} \mathrm{O}\right]^{2-}$ and $\mathrm{NO}$ are the primary photochemical products from SNP in aqueous solution [29], as shown in Equation (1):

$$
\left[\mathrm{Fe}^{\mathrm{II}}(\mathrm{CN})_{5} \mathrm{NO}^{2-}+\mathrm{H}_{2} \mathrm{O} \rightarrow\left[\mathrm{Fe}^{\mathrm{III}}(\mathrm{CN})_{5} \mathrm{H}_{2} \mathrm{O}\right]^{2-}+\mathrm{NO}\right.
$$

On the other hand, it is currently known that NO formation from SNP is also accompanied by cyanide $\left(\mathrm{CN}^{-}\right)$release [30]. This leads to multiple effects including sGC activation and cell toxicity [31,32], and it constitutes an important limitation to the pharmacological use of SNP. In spite of $\mathrm{CN}^{-}$release, SNP has long been a gold standard for the chemical development of new NO donors based on ruthenium complexes. Indeed, SNP is commonly employed as a reference drug when the pharmacological parameters (potency, maximum effect, time-course) of novel drugs are being 
investigated in terms of vasodilation and blood pressure control. In mammals, it is well known that the vasodilating/hypotensive response in mammals occurs readily after SNP injection [29,33,34]. Fast NO dissociation from $\left[\mathrm{Fe}(\mathrm{CN})_{4}(\mathrm{NO})\right]^{2-}$ has been traced. $\left[\mathrm{Fe}(\mathrm{CN})_{5}(\mathrm{NO})\right]^{3-}$ originates after $\mathrm{CN}^{-}$release in physiological $\mathrm{pH}[29,30]$ as shown in Equation (2):

$$
\left[\mathrm{Fe}^{\mathrm{II}}(\mathrm{CN})_{5}(\mathrm{NO})\right]^{3-} \leftrightarrow\left[\mathrm{Fe}(\mathrm{CN})_{4}(\mathrm{NO})\right]^{2-}+\mathrm{CN}^{-}
$$

Bates and co-workers have reported that in the presence of vascular tissue, SNP can release NO via a photochemical process or by decomposition [31]. Biological studies carried out in our research laboratories have confirmed the vasodilating/hypotensive effects of SNP. Our results indicated that SNP releases NO immediately, as measured by amperometric assay in solution. The NO level peaks in the beginning, with subsequent rapid decrease in its concentration within the following $200 \mathrm{~s}$ [35]. Addition of a specific fluorescence probe for NO, DAF-2DA, to the aortic slices exposed to SNP, reveals significantly increased fluorescence intensity ( $\Delta$ FI: $49.4 \% \pm 4.0 \% ; n=5)$ [36]. The system takes $195 \mathrm{~s}$ to reach maximum rat aorta relaxation [35-37]. It is noteworthy that in the case of vascular tissues like the basilar artery, SNP releases NO into the intracellular medium [38,39].

Depending on the NO donor, the released NO species can trigger different action mechanisms, which will result in vasodilation anyway. $\mathrm{NO}$ species have been classified as radicalar $\mathrm{NO}\left(\mathrm{NO}^{0}\right)$ or nitroxyl $\left(\mathrm{NO}^{-}\right.$or $\mathrm{HNO}$ ) species. Some years ago, $\mathrm{NO}^{0}$ was described as biological NO having sGC as the main target, whereas $\mathrm{NO}^{-}$could originate from $\mathrm{NO}$ donors such as Angeli's Salt, to activate $\mathrm{K}^{+}$ channels. Some current studies have reported that both types of NO can emerge in biological systems, but each of them activates types of $\mathrm{K}^{+}$channels [40,41]. It is possible to distinguish between the different types of $\mathrm{NO}$ release by using pharmacological tools like selective scavengers, namely hydroxycobalamin for $\mathrm{NO}^{0}$ and L-cysteine for $\mathrm{NO}^{-} / \mathrm{HNO}[36,42]$.

Our vascular functional studies have indicated that SNP induces maximum vasodilating effect $(101.2 \% \pm 2.8 \%, n=5)$ with high pharmacological potency in rat aorta $\left(\mathrm{pD}_{2}: 8.25 \pm 0.12, n=5\right)$ [37]. Moreover, it releases both types of $\mathrm{NO}, \mathrm{NO}^{0}$ and $\mathrm{NO}^{-}$[36], in accordance with chemical studies reported by Olabe [30]. SNP contains the formally described nitrosonium $\left(\mathrm{NO}^{+}\right)$ligand, which may be redox-interconverted to the corresponding one-electron $(\mathrm{NO})$ and two-electron $\left(\mathrm{NO}^{-} / \mathrm{HNO}\right)$ reduced bound species.

SNP produces its vasodilating effect via sGC activation. This increases cGMP production and certainly activates the GK protein. In turn, this signaling activates $\mathrm{K}^{+}$channels and the sarco/endoplasmic reticulum calcium-ATPase (SERCA) in the VSMC, which diminishes $\left[\mathrm{Ca}^{2+}\right]_{\mathrm{c}}$ and induces vascular relaxation $[37,43,44]$. However, SNP may also relax blood vessels through "cGMPdependent" and "cGMP-independent" mechanisms [45]. Compared with normotensive rat aorta, SNP elicits a similar vasodilation mechanism in hypertensive rat aorta. Nevertheless, in the latter case the vasodilating potency of SNP is lower, because the SERCA activation induced by SNP is impaired [44]. The vasodilating effect induced by SNP is also impaired in vena cava from hypertensive rats, because the functional activity of the $\mathrm{K}^{+}$channels is impaired, as well. Curiously, SERCA activation is not involved in the venorelaxation induced by SNP [46].

Interestingly, SNP has been considered an endothelium-independent relaxant agent for many years; its effect has always been attributed to its direct action on the VSMC. Recently, our research group has demonstrated that SNP raises $\left[\mathrm{Ca}^{2+}\right]_{\mathrm{c}}$ in endothelial cells via activation of $\mathrm{Ca}^{2+}$ channels. This 
endothelial effect increases the NOS activity, thereby inducing NO production and potentiating the relaxant effect induced by SNP [47]. On the basis of all these findings, the mechanism proposed for the SNP-induced is the one shown in Figure 1.

Figure 1. Proposed nitric oxide release and vasodilating mechanism prompted by sodium nitroprusside (SNP). The colored circles represent atoms in the chemical structure. Legend: NOS $=$ Nitric Oxide Synthase, $\mathrm{sGC}=$ soluble guanylyl cyclase, $\mathrm{GK}=\mathrm{G}$ Kinase Protein, $\mathrm{SERCA}=$ sarco/endoplasmic reticulum calcium-ATPase, $\mathrm{Ca}^{2+}=$ calcium, $\mathrm{K}^{+}=$potassium, $\left[\mathrm{Ca}^{2+}\right]_{\mathrm{c}}=$ cytosolic calcium concentration.

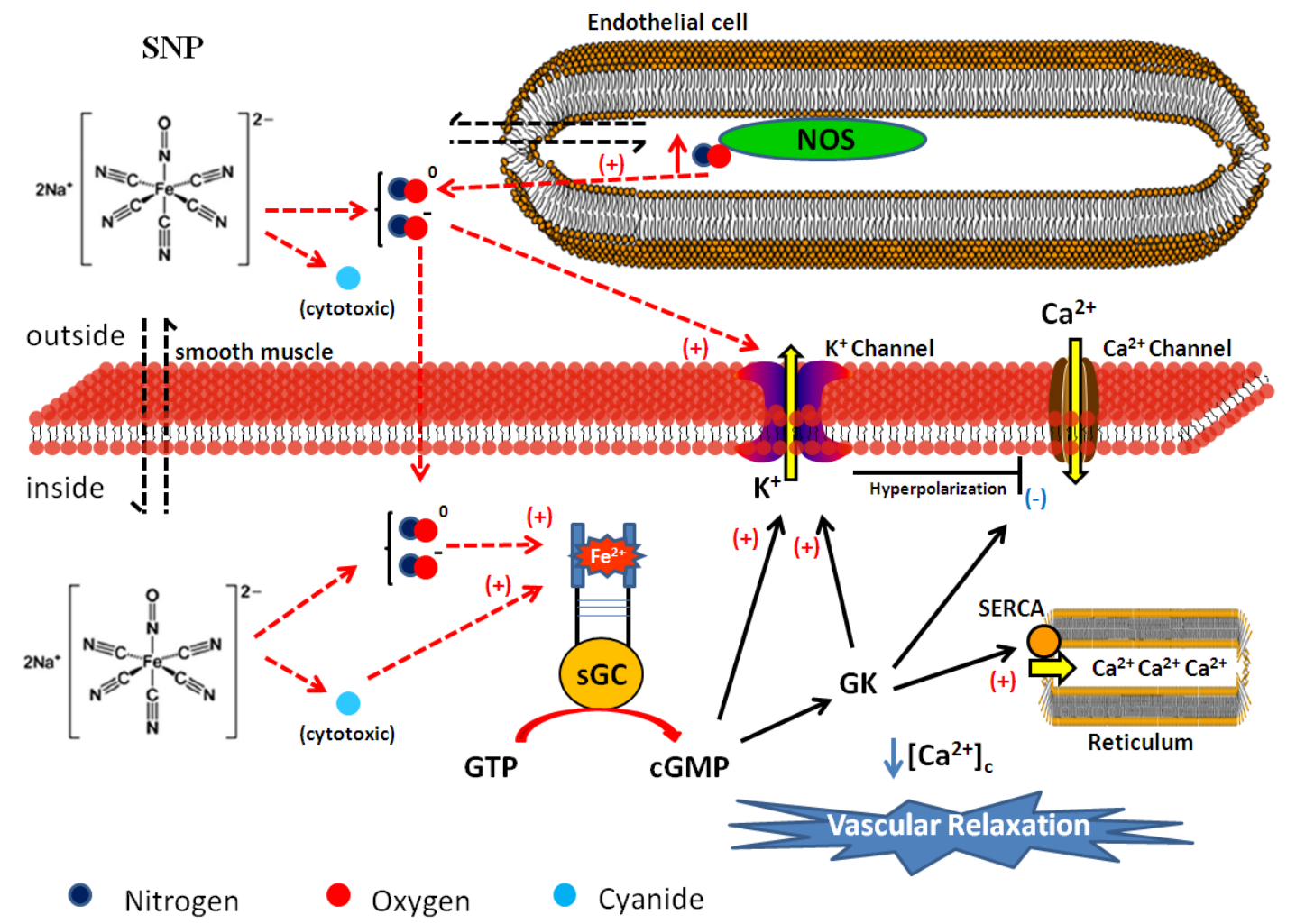

Our in vivo analyses have attested that SNP induces a faster and greater hypotensive effect as compared with the ruthenium-based NO donor complex Terpy ([Ru(tpy)(NH.NHq)NO$\left.]^{3+}\right)$ [34]. Compared with normotensive Wistar rats, SNP induces a stronger hypotensive effect in spontaneous hypertensive rats (SHR) and in normotensive rats. The effect is immediate, and the hypotensive effect is associated with increased heart rate in SHR and normotensive rats [48].

\section{Development of Ruthenium-Derived NO Donor Complexes}

Ruthenium compounds containing nitrogen oxide as one of their ligands generally exist as hexacoordinated species like $\left[\operatorname{RuL}_{5}\left(\mathrm{NO}_{\mathrm{x}}\right)\right]^{\mathrm{n}+}$. Studies on such ruthenium complexes involve the reactivity of the coordinated nitrogen oxide ligands mainly, which include redox properties, photochemical reactivity, and kinetic aspects. The influence of co-ligands " $L$ " on the $\left[\mathrm{RuL}_{5}(\mathrm{NO})\right]^{\mathrm{n}+}$ species is remarkable and will drive all the properties that are directly related to the nitrogen oxide ligands.

The compounds described in this work have been developed by our group and will be divided into two classes: (i) $\left[\mathrm{Ru}\left(\mathrm{N}_{4}\right) \mathrm{L}(\mathrm{NO})\right]^{\mathrm{n}+}$, which contains a tetraazacoordinated ligand as co-ligand $\left(\mathrm{N}_{4}\right.$ is 
tetraazamacrocyclic ligand or phthalocyanine; $n$ could be $2+, 1+$, or 0 ); and (ii) $\left[\mathrm{Ru}(\mathrm{L})_{\mathrm{x}} \mathrm{L}_{\mathrm{y}} \mathrm{NO}\right]^{\mathrm{n}+}$ (bpy refers to 2,2'-bipyridine or tpy refers to 2,2':6',2"-terpyridine). Both classes of compounds are stable in aqueous solution for at least $24 \mathrm{~h}$. The present article will describe the physicochemical and the pharmacological properties of a specific class of ruthenium compounds.

\subsection{Tetraazacyclotetradecane Ruthenium Complexes}

The tetraazacyclotetradecane ruthenium complexes synthesized by our group bear 1,4,8,11tetrazacyclotetradecane (cyclam) or 1,4,8,12-tetrazacyclopentadecane ([15]aneN 4 ) ligands coordinated to ruthenium(II) or (III) compounds (Figure 2). Both species are quite soluble in aqueous solution; the macrocycle (MAC) chelates the metal ion, which in principle offers extra stability to the complex as compared with the open chain ligand [49]. Generally, the ruthenium compound bearing these ligands are isolated as $\left[\mathrm{RuCl}_{2}(\mathrm{MAC})\right] \mathrm{Cl}$. When $\mathrm{MAC}$ refers to [15] aneN $\mathrm{N}_{4}$, only the species with trans-geometry occurs. As for MAC corresponding to cyclam, the cis/trans-geometries are achieved. We have successfully prepared both $\left[\mathrm{RuCl}_{2}(\mathrm{MAC})\right] \mathrm{Cl}$ complexes in the trans-geometry, because the resulting ruthenium(III) complex is inert to the chloro ligand. The latter phenomenon is partly due to the affinity of the ruthenium(III) ion for charged negative ligands and partly due to hydrogen bonding between MAC and the bound chloride in trans-[ $\left.\mathrm{RuCl}_{2}(\mathrm{MAC})\right] \mathrm{Cl}$ [50,51]. Bearing in mind that the chelate ligand MAC on the ruthenium complex is inert, and that the chloro ligand becomes labile after reduction of the metal ion to ruthenium(II), it is possible to synthesize and isolate trans-[Ru(NO)Cl(MAC) $] \mathrm{X}\left(\mathrm{X}=\mathrm{Cl}^{-}\right.$or $\left.\mathrm{PF}_{6}{ }^{-}\right)$in good yields and purity.

Figure 2. Nitrosyl macrocyclic ruthenium complexes structure. (A) trans$\left[\mathrm{RuCl}\left([15] \mathrm{ane}_{4}\right) \mathrm{NO}\right]^{2+}$ and $(\mathbf{B})$ trans- $[\mathrm{RuCl}(\text { cyclam}) \mathrm{NO}]^{2+}$. The colored circles represent atoms in the chemical structure (cyan: carbon; blue: nitrogen; green: chlorine; red: oxygen; white: hydrogen and gray: ruthenium).

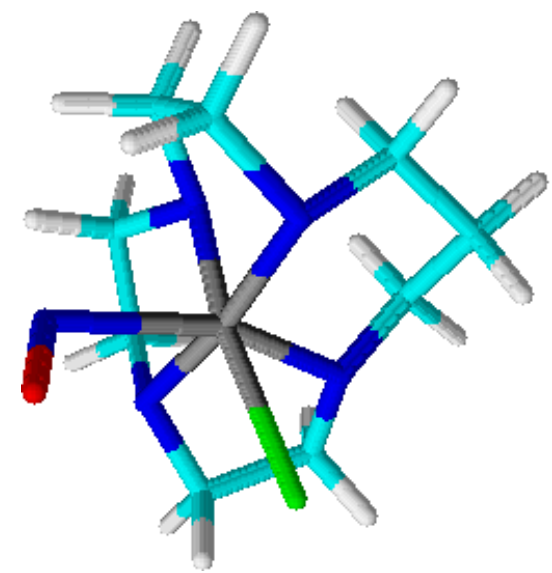

(A)

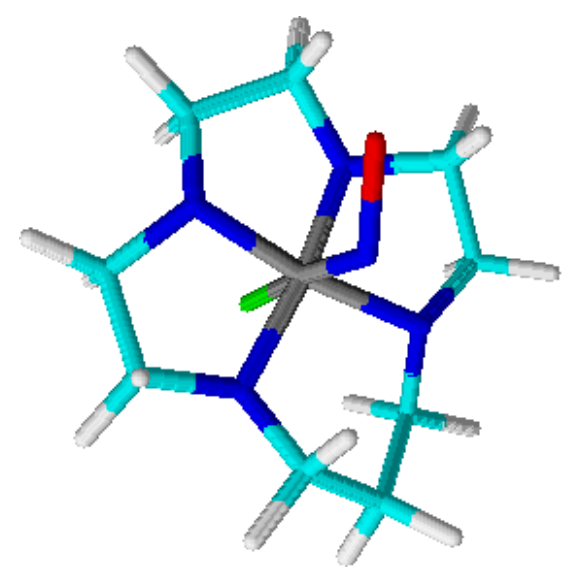

(B)

Coordinated NO can assume three different forms depending on the oxidation state, namely nitroxyl for $\mathrm{NO}^{-}$, nitric oxide for $\mathrm{NO}^{0}$, and nitrosyl for $\mathrm{NO}^{+}$. For trans-[Ru(NO)Cl(MAC)$]^{+}$, the nitrogen oxide ligand has nitrosyl character, as verified by FTIR spectral analysis. Regarding the structure of $[\mathrm{Ru}-\mathrm{NO}]^{3+}$, the $v_{(\mathrm{NO})}$ values range from 1,700 to $2,000 \mathrm{~cm}^{-1}[52-55]$. The $v(\mathrm{NO})$ stretching for trans$[\mathrm{RuCl}(\text { cyclam }) \mathrm{NO}]^{2+}$ and trans- $\left[\mathrm{RuCl}\left([15] \mathrm{ane}_{4}\right) \mathrm{NO}\right]^{2+}$ appears at 1,864 and $1,860 \mathrm{~cm}^{-1}$, respectively. 
Both values indicate that a high degree of positive charge resides on the coordinated nitrosyl, so it is better to describe ruthenium as ruthenium(II). The electrochemical characterization of trans$[\mathrm{RuCl}(\text { cyclam }) \mathrm{NO}]^{2+}$ and trans- $\left[\mathrm{RuCl}\left([15] \mathrm{ane}_{4}\right) \mathrm{NO}\right]^{2+}$ shows that both macrocyclic ruthenium complexes could undergo reduction in the aqueous solution window potential via two electrochemical steps, as illustrated in Scheme 1.

Scheme 1. Electrochemical process involved in nitrosyl macrocyclic ruthenium complex.

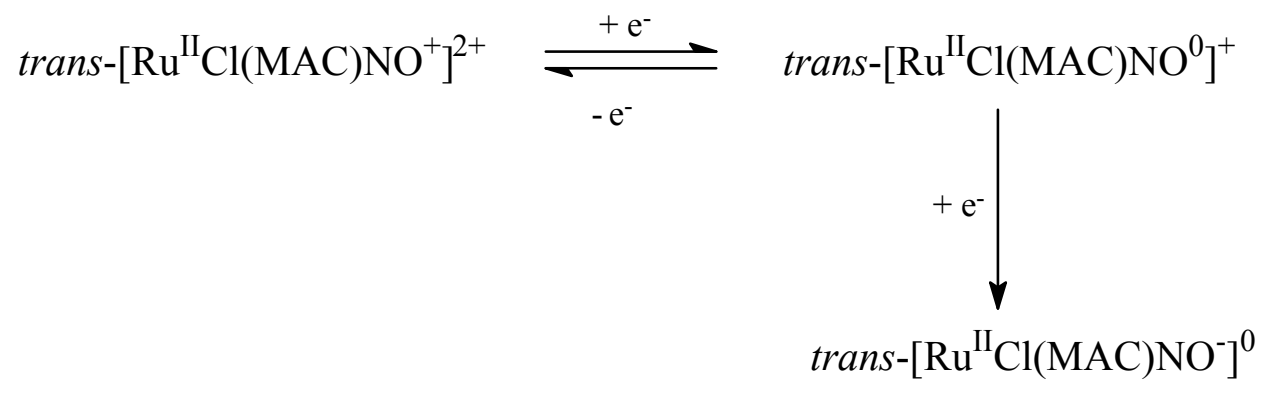

The highest reduction process is almost reversible in the cyclic voltammetry timescale and refers to $\mathrm{NO}^{+/ 0}$. The second reduction process is irreversible and corresponds to the $\mathrm{NO}^{0 /-}$ process [52-55]. Using $0.1 \mathrm{M} \mathrm{KCl}$ as electrolyte, the mono-reduction electrochemical process for the trans$[\mathrm{RuCl}(\text { cyclam }) \mathrm{NO}]^{2+}$ and trans- $\left[\mathrm{RuCl}\left([15] \mathrm{ane}_{4}\right) \mathrm{NO}^{2+}\right]^{2}$ complexes takes place at 122 and $280 \mathrm{mV}$ vs. $\mathrm{Ag} / \mathrm{AgCl}$, respectively. At very low cyclic voltammetry scan rate, the $\mathrm{NO}^{+/ 0}$ couple is almost irreversible, which suggests that a chemical reaction follows the electrochemical step. The controlled electrolyses reduction process conducted in the presence of the NO sensor provides the best explanation for the process: NO release occurs after the reduction process (Scheme 2). Therefore, these kinds of compounds are applicable as nitric oxide delivery agents for pharmacological assays. Indeed, some reducing biomolecules like norepinephrine or ascorbic acid can promote such reduction process [35].

Scheme 2. Kinetic process related to the electron reduction of nitrosyl macrocyclic ruthenium complex.

$$
\begin{gathered}
\text { trans }-\left[\mathrm{Ru}^{\mathrm{II}} \mathrm{Cl}(\mathrm{MAC}) \mathrm{NO}\right]^{2+} \stackrel{+\mathrm{e}^{-}}{\longrightarrow} \operatorname{trans}-\left[\mathrm{Ru}^{\mathrm{II}} \mathrm{Cl}(\mathrm{MAC}) \mathrm{NO}\right]^{+} \\
+\mathrm{H}_{2} \mathrm{O} \downarrow-\mathrm{NO}^{0} \\
\text { trans }-\left[\mathrm{Ru}^{\mathrm{II}} \mathrm{Cl}(\mathrm{MAC}) \mathrm{H}_{2} \mathrm{O}\right]^{+}+\mathrm{NO}^{0}
\end{gathered}
$$

Bonaventura et al. [35] have reported pharmacological studies involving reduction of trans$\left[\mathrm{RuCl}\left([15] \mathrm{ane}_{4}\right) \mathrm{NO}\right]^{2+}$ using norepinephrine, a well-known vasoconstrictor, as the biological reducing agent. These studies will be properly discussed later in this paper. From a chemical viewpoint, the reduction of a nitrosyl ruthenium complex depends on the formation of a supramolecule between norepinephrine and the ruthenium complex, mediated by a phosphate bridge. The phosphate ion interacts with trans-[RuCl([15]ane 4$) \mathrm{NO}^{2+}$ by hydrogen bonding and plays a crucial role in the reduction of the nitrosyl ruthenium complex [23]. 
In addition to NO release via chemical reduction, it is also possible to control NO release by light irradiation. Based on the UV-visible spectral analysis and measurement with the NO sensor, we have described the photochemical process for trans-[Ru(NO)Cl(MAC) $]^{+}$as illustrated in Scheme 3.

Scheme 3. General photochemical pathway related to nitrosyl macrocyclic ruthenium complex.

$$
\begin{gathered}
\text { trans }-\left[\mathrm{Ru}{ }^{\mathrm{II}} \mathrm{Cl}(\mathrm{MAC}) \mathrm{NO}\right]^{2+} \stackrel{\mathrm{h} \nu}{\longrightarrow} \text { trans }-\left[\mathrm{Ru}^{\mathrm{III}} \mathrm{Cl}(\mathrm{MAC}) \mathrm{NO}\right]^{3+} \\
+\mathrm{H}_{2} \mathrm{O} \downarrow-\mathrm{NO}^{0} \\
\text { trans }-\left[\mathrm{Ru}^{\mathrm{III}} \mathrm{Cl}(\mathrm{MAC}) \mathrm{H}_{2} \mathrm{O}\right]^{2+}+\mathrm{NO}^{0}
\end{gathered}
$$

The photoproduct of the trans-[RuCl(cyclam)NO$]^{2+}$ and trans-[RuCl([15]ane 4$) \mathrm{NO}^{2+}$ complexes obtained by light irradiation at $355 \mathrm{~nm}$ is aqua(macrocyclic)ruthenium(III), with consequent NO release. The measured NO quantum yield $(\phi N O)$ is 0.1 and 0.6 eisntein $\mathrm{mol}^{-1}$ for the trans$[\mathrm{RuCl}(\text { cyclam }) \mathrm{NO}]^{2+}$ and trans- $\left[\mathrm{RuCl}\left([15] \mathrm{ane}_{4}\right) \mathrm{NO}\right]^{2+}$ complexes, respectively. The contribution of the nitrosyl ligand to the lowest unoccupied molecular orbital (LUMO) best explains the different quantum yields of these complexes. Indeed, LUMO seems to be larger in trans-[RuCl([15]ane 4$) \mathrm{NO}^{2+}$ than in trans-[RuCl(cyclam)NO $]^{2+}$ [56]. Observation of the chemical and the photochemical properties as well as the attainment of different pharmacological results for the various macrocyclic nitrosyl ruthenium complexes are a consequence of the macrocyclic ring size [56].

In the rat aorta tissue, trans-[RuCl$\left([15] \mathrm{ane}_{4}\right) \mathrm{NO}^{2+}$ releases $\mathrm{NO}$ by chemical reduction. The release of NO from this reduced compound is slower than the release of NO from SNP. However, this ruthenium compound sustains high levels of NO release, which reaches a maximum at $5 \mathrm{~min}$ [35]. As shown previously, in artery pre-contracted with norepinephrine, the complex trans-[RuCl([15] $\left.\left.\mathrm{ane}_{4}\right) \mathrm{NO}\right]^{2+}$ induces relaxation in a concentration-dependent way. The time necessary to achieve maximal relaxation is $595 \mathrm{~s}$, which is longer as compared with the time that SNP takes to induce relaxation [35]. However, Bonaventura [35] demonstrated that the relaxing effect of trans-[RuCl$\left.\left([15] \mathrm{ane}_{4}\right) \mathrm{NO}\right]^{2+}$ is completely blocked in aorta pre-contracted with high $\mathrm{KCl}$ concentration $(60 \mathrm{mM})$. At this large concentration, $\mathrm{KCl}$ induces membrane depolarization, voltageoperated $\mathrm{Ca}^{2+}$ channels activation, and $\mathrm{Ca}^{2+}$ influx, to stimulate the contractile machinery.

To study vascular relaxation, it is necessary to contract the vessels. The choice of the contractile agent is very important, since it will remain in contact with the vessel during the course of the relaxation experiment. Norepinephrine stimulates contraction through $\alpha$-adrenoceptor activation and intracellular as well extracellular calcium mobilization, whereas $\mathrm{KCl} 60 \mathrm{mM}$ induces contraction through extracellular calcium influx. It is important to consider that $\mathrm{KCl}$ at this extracellular concentration blocks the $\mathrm{K}^{+}$channels, which play a pivotal role in the NO-induced vascular relaxation. We have also studied the relaxant effect of trans- $\left[\mathrm{RuCl}\left([15] \mathrm{ane}_{4}\right) \mathrm{NO}\right]^{2+}$ in the prostaglandin $\mathrm{F}_{2 \alpha}$ $\left(\mathrm{PGF}_{2 \alpha}\right)$-induced contraction [57]. In denuded-endothelium aortic ring contracted with $\mathrm{PGF}_{2 \alpha}$, the photo-induction of the complex trans-[RuCl([15] $\left.\left.\mathrm{ane}_{4}\right) \mathrm{NO}\right]^{2+}$ with $\mathrm{UV}$ light induces complete relaxation in $50 \mathrm{~s}$. These results suggest that this relaxation stems from NO release from preformed 
endogenous NO stores upon UV light irradiation. Increasing concentrations of $\mathrm{KCl}$ (as the pre-contractile agent) decreases the relaxation induced by nitrosothiols NO donors (GSNO and NACysNO) as compared with phenylephrine-contracted aorta [58].

The low cytotoxic characteristics of ruthenium-derived complexes are well known $[59,60]$. The trans- $\left[\mathrm{RuCl}\left([15] \mathrm{aneN}_{4}\right) \mathrm{NO}\right]^{2+}$ complex is not toxic to the VSMC in the concentration that it induces maximum relaxation of denuded rat aorta.

\subsubsection{Vasodilating Effect in Normotensive and Hypertensive Rat Vessels}

Several ruthenium-derived complexes induce relaxation in isolated vessels of normotensive and hypertensive rats. However, the relaxation induced by trans- $\left[\mathrm{RuCl}\left(15-\mathrm{aneN}_{4}\right) \mathrm{NO}\right]^{2+}$ is less potent than the vascular relaxation induced by SNP. Interestingly, the efficacy is similar between these complexes. The bis-oxonol sensitive probe (DIBAC2) can detect changes in the membrane potential of rat aorta smooth muscle cells. This probe has revealed that cell membranes from renal hypertensive $2 \mathrm{~K}-1 \mathrm{C}$ rat aorta are more depolarized $(-55 \mathrm{mV})$ than $2 \mathrm{~K}$ normotensive rat aorta cell membranes $(-65 \mathrm{mV})[61]$. In $2 \mathrm{~K}-1 \mathrm{C}$ aorta cells, a $\mathrm{KCl}$ concentration of only $10 \mathrm{mM}$ is necessary to induce complete depolarization as compared with the concentration of $40 \mathrm{mM}$ required in the case of $2 \mathrm{~K}$ aorta cells. An electrophysiological investigation into the cells membrane has shown that the resting potential is more electronegative in $2 \mathrm{~K}$ than in $2 \mathrm{~K}-1 \mathrm{C}$ aorta cells membrane, and that the hyperpolarization induced by acetylcholine is lower in $2 \mathrm{~K}-1 \mathrm{C}$ than in $2 \mathrm{~K}$ [62].

The ruthenium-derived complex trans-[RuCl([15]-aneN 4$) \mathrm{NO}^{2+}$ has led to intriguing findings. Selective (4-aminopyridine, apamin, iberiotoxin, glibenclamide) and also non-selective blockers of $\mathrm{K}^{+}$ channels (TEA) do not affect the relaxation induced by trans-[RuCl([15]-aneN 4$) \mathrm{NO}]^{2+}$ in $2 \mathrm{~K}-1 \mathrm{C}$ rat aorta. This could be the reason for the impaired relaxation observed in this hypertension model. On the other hand, all the studied $\mathrm{K}^{+}$channel blockers abate the trans-[RuCl([15]-ane $\left.\mathrm{N}_{4}\right) \mathrm{NO}^{2+}{ }^{2}$-induced relaxation of normotensive $2 \mathrm{~K}$ rat aorta [63].

The vascular functional studies have indicated that trans-[RuCl([15]-aneN 4$) \mathrm{NO}^{2+}$ releases both types of $\mathrm{NO}, \mathrm{NO}^{0}$ and $\mathrm{NO}^{-}$, and its vasodilating effect originates from $\mathrm{K}^{+}$channel activation in the cGMP-dependent and -independent pathways, which diminish $\left[\mathrm{Ca}^{2+}\right]_{\mathrm{c}}$ and therefore induce vascular relaxation. However, $\mathrm{K}^{+}$channel activation in the hypertension model seems to be impaired as compared with normotensive rat aorta. On the basis of these results, Figure 3 depicts the mechanism proposed for the vasodilatation induced by trans-[RuCl([15]-aneN 4$) \mathrm{NO}^{2+}$.

\subsubsection{Effects of the Macrocyclic Ruthenium Complexes on Arterial Pressure Control}

Although no in vitro functional studies on the trans-[RuCl(cyclam)NO$]^{2+}$ complex exists, Marcondes et al. [64] have reported how this complex affects the blood pressure in vivo. These authors found that, compared with SNP, trans-[RuCl(cyclam)NO$]^{2+}$ induces 20 times longer hypotensive effect in both normotensive and hypertensive rats. They also found that sGC inhibitor or NO scavenger completely inhibits this effect. 
Figure 3. Proposed nitric oxide release and cellular mechanisms involved in the vasodilation promoted by trans-[RuCl(15-aneN $\left.)_{4}\right){ }^{+}$(15ane). The colored circles represent atoms in the chemical structure. The hydrogen atom has been omitted in the structure. Legend: $\mathrm{sGC}=$ soluble guanylyl cyclase, $\mathrm{GK}=\mathrm{G}$ Kinase Protein, $\mathrm{Ca}^{2+}=$ calcium, $\mathrm{K}^{+}=$potassium, $\left[\mathrm{Ca}^{2+}\right]_{\mathrm{c}}=$ cytosolic calcium concentration.

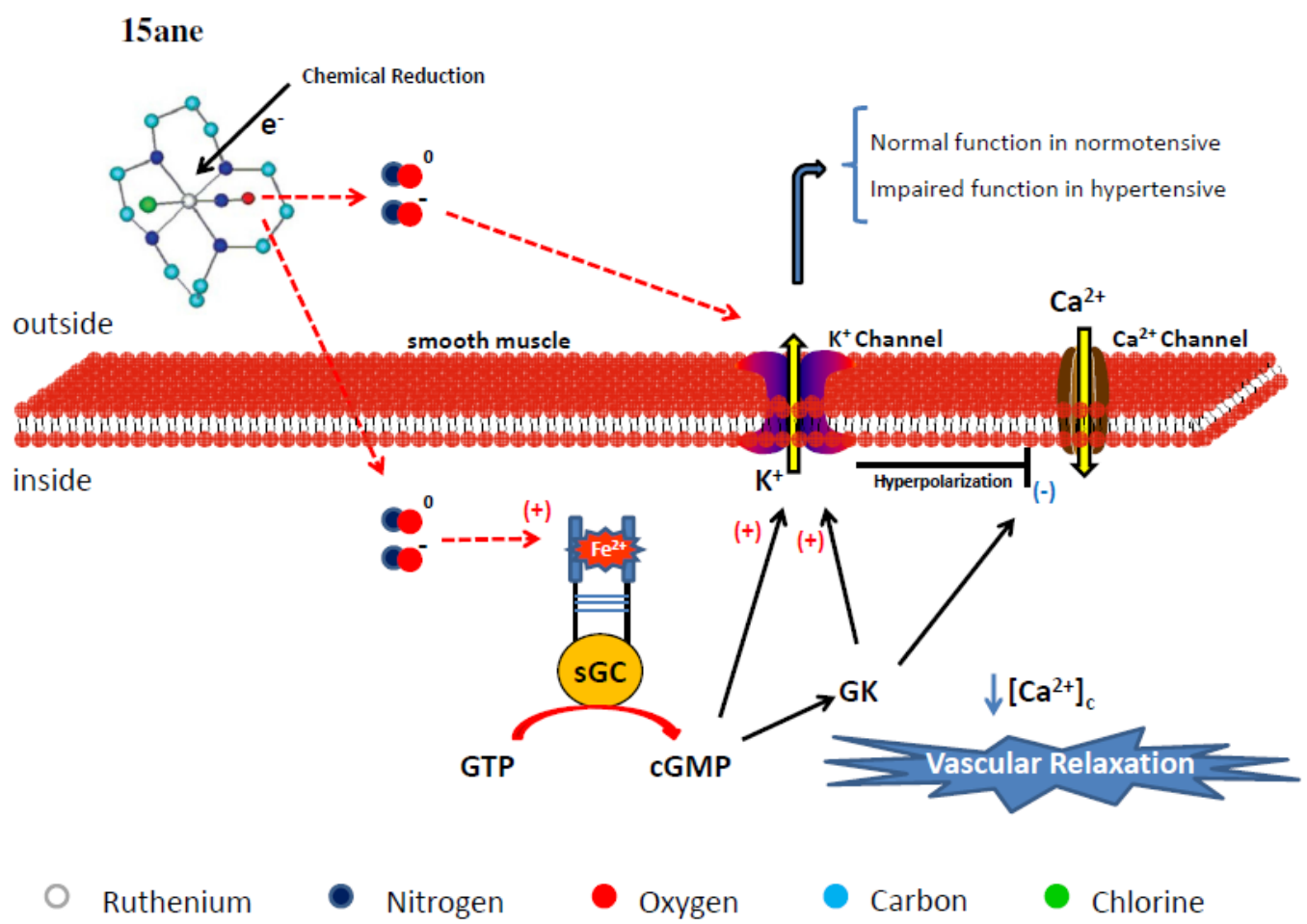

On the other hand, our research group has observed that the hypotensive effect prompted by trans$\left[\mathrm{RuCl}\left([15]-\mathrm{aneN}_{4}\right) \mathrm{NO}\right]^{2+}$ depends on the severity of the hypertensive state. In severe renal hypertensive rats $(2 \mathrm{~K}-1 \mathrm{C})$, the trans- $\left[\mathrm{RuCl}\left([15]-\right.\right.$ aneN $\left._{4}\right) \mathrm{NO}^{2+}$ induces a more pronounced effect than in mild hypertensive rats [65]. Comparison between two doses of trans-[RuCl([15]-aneN $\left.)_{4}\right) \mathrm{NO}^{2+}$, namely $0.1 \mathrm{mM} / \mathrm{kg}$ and $10 \mathrm{mM} / \mathrm{kg}$, reveals that the lower dose does not have hypotensive effect on normotensive or moderate hypertensive rats, but it impacts severe hypertensive rats. The higher dose of the $\mathrm{NO}$ donor trans- $\left[\mathrm{RuCl}\left([15]-\mathrm{aneN}_{4}\right) \mathrm{NO}^{2+}\right.$ reduces the mean arterial pressure of all hypertensive rats. In normotensive $2 \mathrm{~K}$ rats, both doses of trans- $\left[\mathrm{RuCl}\left(15-\mathrm{aneN}_{4}\right) \mathrm{NO}\right]^{2+}$ elicit a much lower hypotensive effect. To induce the hypotensive effect, trans- $\left[\mathrm{RuCl}\left(15-\mathrm{aneN}_{4}\right) \mathrm{NO}\right]^{2+}$ requires higher doses as compared with SNP.

Considering the series trans-[RuCl(mac)NO $]^{2+}$ and trans- $\left[\mathrm{Ru}\left(\mathrm{NH}_{3}\right)_{4}(\mathrm{~L}) \mathrm{NO}\right]^{3+}$, it is possible to correlate the rate of $\mathrm{NO}$ release with the stability of the reduced [ $\mathrm{Ru}(\mathrm{II})-\mathrm{NO}^{\circ}$ ] compounds. This stability will depend on the electron density of the metal centers and on the nature of the ancillary ligands. In these series, the kinetics and thermodynamic properties of NO are sensitive to the ligand present in the trans position in the coordination sphere $[64,66]$. In this context, our group aimed to develop a new class of nitrosyl ruthenium complexes that would allow us to modulate the NO release elicited by co-ligands with $\pi$-acceptor character. 


\subsection{Polypyridine Ruthenium Complexes}

Cis-[Ru(bpy $\left.)_{\mathrm{x}} \mathrm{L}_{\mathrm{y}} \mathrm{NO}_{\mathrm{z}}\right]^{\mathrm{n+}}(\mathrm{L}=$ 2,2'-bipyridine, 2,2':6',2"-terpyridine, or pyridine-like ligands) will represent the polypyridine ruthenium complexes described in this paper. When these pyridine derivative ligands coordinate to ruthenium(II), they generally establish back-bonding with the metal ion. On the other hand, the nitrogen oxide ligand $\left(\mathrm{NO}_{\mathrm{z}}\right)$ is described as nitrosyl species $\left(\mathrm{NO}^{+}\right)$or Nitrite $\left(\mathrm{NO}_{2}{ }^{-}\right)$bound to ruthenium(II). This work will discuss two classes of these compounds, named cis- $\left[\mathrm{Ru}(\text { bpy })_{2} \mathrm{~L}\left(\mathrm{NO}_{\mathrm{z}}\right)\right]^{\mathrm{n}+}(n=3+, 2+, 1+, 0)$ and $\left[\mathrm{Ru}(\mathrm{tpy}) \mathrm{L}^{\prime}\left(\mathrm{NO}_{\mathrm{z}}\right)\right]^{\mathrm{n}+}\left(\mathrm{L}^{\prime}=2,2^{\prime}\right.$-bipyridine or 1,2-benzoquinonediamine) (Figure 4). The nature of $\mathrm{NO}_{\mathrm{z}}$ depends on the $\mathrm{pH}$ of the solution; at $\mathrm{pH}>4.0$, the ruthenium species is normally ascribed as nitro ligand coordinated to ruthenium(II).

Figure 4. Chemical structure of polipyridines ruthenium complexes (A) cis$\left[\mathrm{RuCl}(\mathrm{bpy})_{2} \mathrm{NO}\right]^{2+}$, (B) cis-[Ru(bpy $\left.)_{2}(\mathrm{py}) \mathrm{NO}\right]^{3+}$ and (C) $[\mathrm{Ru}(\mathrm{tpy})(\mathrm{NH} . \mathrm{NHq}) \mathrm{NO}]^{3+}$. The colored circles represent atoms in the chemical structure (cyan: Carbon; blue: Nitrogen; green: Chlorine; red: Oxygen; white: Hydrogen and gray: Ruthenium).

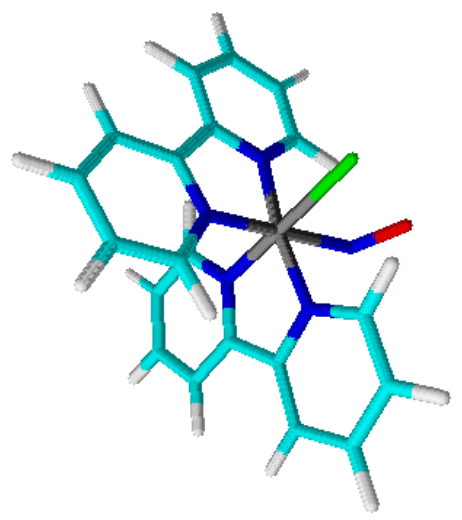

(A)

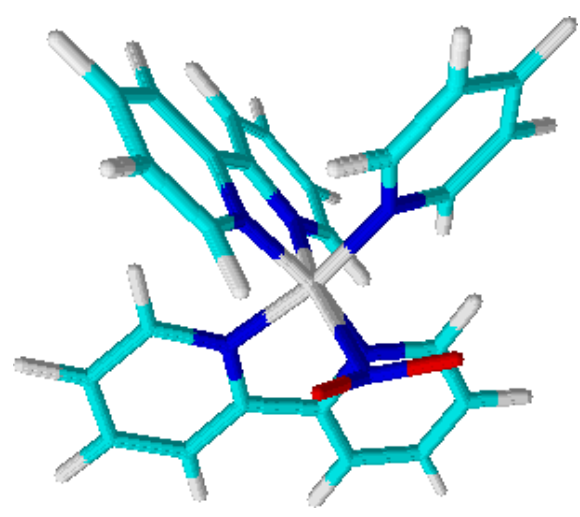

(B)

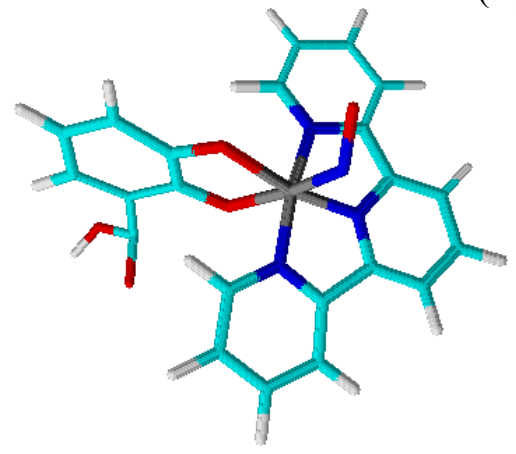

(C)

The nitrosyl polipyridine ruthenium complex displays UV-visible spectrum with intense bands in the ultraviolet region [67-70]. These bands are due to intraligand transition originated from unsaturated ligands and to metal ligand charge transfer (MLCT) bands $d \pi\left(\mathrm{Ru}^{\mathrm{II}}\right)-\pi^{*}$ (polypyridine + $\mathrm{NO}^{+}$). No bands arise in the visible region [71]. In addition to the intraligand bands, the nitro species presents bands in the region of $450 \mathrm{~nm}$, characterized as MLCT $\mathrm{d} \pi\left(\mathrm{Ru}^{\mathrm{II}}\right)-\pi^{*}$ ( polypyridine). Figure 5 brings the electronic spectrum of representative complexes of ruthenium polypyridine species. 
Figure 5. UV-visible electronic spectra of $\left[\mathrm{RuNO}_{2}(\mathrm{tpy})(\mathrm{bpy})\right]^{2+}$ (dashed line) and $[\mathrm{Ru}(\mathrm{tpy})(\mathrm{bpy}) \mathrm{NO}]^{3+}$ (solid line) in aqueous solution.

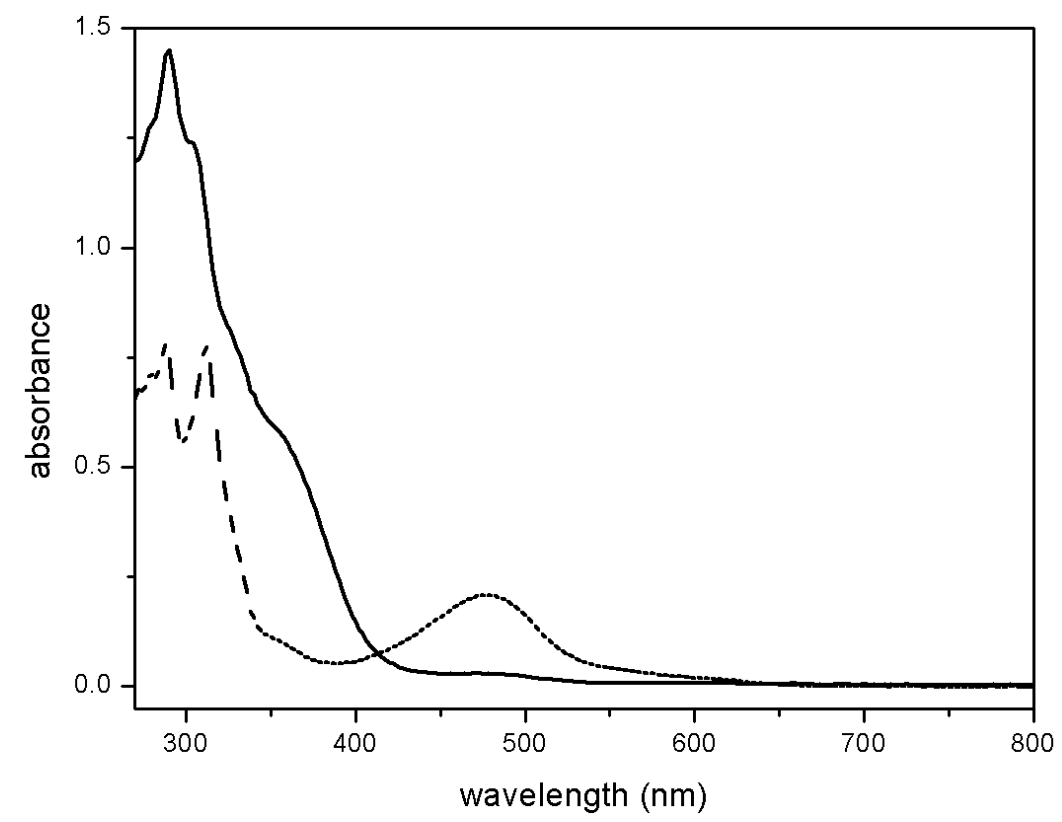

Electrochemical studies conducted on these nitrosyl bipyridine species reveal two redox processes between +1 to $-1 \mathrm{~V}$ vs. $\mathrm{Ag} / \mathrm{AgCl}$, as previously described for tetraazamacrocyclic compounds in this paper. Cyclic voltammetry results and FTIR observations evidence that the electron density under ruthenium(II) influences the $\mathrm{NO}^{+/ 0}$ process and depends on the back-bonding of co-ligands. Table 1 lists the $\mathrm{NO}^{+/ 0}$ reduction potential and the $v_{(\mathrm{NO})}$ stretching. Apparently, the $\sigma$ - and $\pi$-donor character of " $\mathrm{L}$ " in cis-[Ru(bpy $\left.)_{2} \mathrm{~L}(\mathrm{NO})\right]^{2+}$ lowers the reduction potential of the nitrosyl ligand, as observed for $\mathrm{L}^{2} \mathrm{Cl}^{-}$ as compared with the pyridine (py), 4-picoline (4-pic), and 4-acetylpyridine (4-acpy) ligands, which exert $\pi$-acceptor character only $[52,53,72,73]$. A similar correlation is true for the $\left[\mathrm{Ru}(\operatorname{tpy}) \mathrm{L}_{\mathrm{n}} \mathrm{NO}\right]^{\mathrm{n}+}$ complex [55].

Table 1. Infrared data and $\mathrm{NO}^{+/ 0}$ redox potential for nitrosyl polypyridine ruthenium complexes.

\begin{tabular}{|c|c|c|}
\hline Compounds & $\mathrm{v}(\mathrm{NO}) \mathrm{cm}^{-1 \mathrm{a}}$ & $\mathrm{E}_{1 / 2} \mathrm{NO}^{+/} \mathrm{NO}^{0}(\mathrm{~V})$ vs. Ferrocene ${ }^{\mathrm{b}}$ \\
\hline$c i s-\left[\mathrm{Ru}^{\mathrm{II}}(\mathrm{bpy})_{2}(\mathrm{NO}) \mathrm{Cl}\right]^{2+}$ & 1940 & -0.21 \\
\hline$c i s-\left[\mathrm{Ru}^{\mathrm{II}}(\mathrm{bpy})_{2}(\mathrm{py})(\mathrm{NO})\right]^{3+}$ & 1944 & 0.12 \\
\hline$c i s-\left[\mathrm{Ru}^{\mathrm{II}}(\mathrm{bpy})_{2}(4-\mathrm{pic})(\mathrm{NO}]^{3+}\right.$ & 1947 & 0.14 \\
\hline$c i s-\left[\mathrm{Ru}^{\mathrm{II}}(\mathrm{bpy})_{2}(4-\mathrm{acpy})(\mathrm{NO})\right]^{3+}$ & 1943 & 0.16 \\
\hline$\left[\mathrm{Ru}^{\mathrm{II}} \mathrm{Cl}_{2}(\mathrm{tpy})(\mathrm{NO})\right]^{3+}$ & 1870 & $-0.51^{\mathrm{c}}$ \\
\hline$\left[\mathrm{Ru}^{\mathrm{II}}(\mathrm{tpy})(\mathrm{bpy})(\mathrm{NO})\right]^{3+}$ & 1944 & +0.053 \\
\hline$\left[\mathrm{Ru}^{\mathrm{II}}(\mathrm{tpy})(\mathrm{NH} . \mathrm{NHq})(\mathrm{NO})\right]^{3+}$ & 1888 & - \\
\hline
\end{tabular}

a: KBr pellets; b: Acetonitrile solvent; Hirano et al., 2001 [72].

The electron density under nitrosyl also influences its nucleophilic character [74]. This is easy to verify upon varying the $\mathrm{pH}$. Scheme 4 describes the reactivity of representative species of the nitrosyl bipyridine ruthenium complex. The rate equilibrium constant $\left(\mathrm{K}_{\mathrm{eq}}\right)$ depends on the $\mathrm{L}$ that exists in $c i s-[\mathrm{Ru}(\mathrm{bpy}) \mathrm{LNO}]^{\mathrm{n}+}$. 
Scheme 4. Interconversion of nitrosyl-nitrite coordinated to ruthenium(II).

$$
c i s-\left[\mathrm{RuL}(\mathrm{bpy})_{2} \mathrm{NO}\right]^{3+}+\mathrm{OH}^{-} \stackrel{\mathrm{K}_{\mathrm{eq}}}{\rightleftharpoons} c i s-\left[\mathrm{Ru}\left(\mathrm{NO}_{2}\right) \mathrm{L}(\mathrm{bpy})_{2}\right]^{+}+\mathrm{H}_{2} \mathrm{O}
$$

The Keq values measured for the 4-pic, py, and 4-acpy complexes are $3.8 \times 10^{20}, 1.6 \times 10^{21}$, and $3.2 \times 10^{21} \mathrm{~L}^{2} \mathrm{~mol}^{-2}$, respectively. Keq increases with the $\pi$-acceptor capacity of the $\mathrm{L}$ ligand, which suggests that competition regarding back-bonding of the metal results in low electronic density on the nitrosyl group [53].

Depending on the irradiated light wavelength, the nitrosyl bipyridine ruthenium complexes are also photochemically active and release NO. To avoid nitrite formation as a result of the nucleophilic attack of $\mathrm{OH}^{-}$, photolysis of polypyridyl ruthenium complexes has to be carried out in buffer solution pH 2.0. Studies on the photoreactivity of the nitrosyl complex reveal a change in the UV-Visible spectrum; an NO-sensor aids quantification of the released NO. For all the polypyridyl nitrosyl ruthenium complexes irradiated with light of $355 \mathrm{~nm}$, the absorption in the region of $330 \mathrm{~nm}$ (MLCT band attributed to $\mathrm{d} \pi\left(\mathrm{Ru}^{\mathrm{II}}\right) \rightarrow \pi^{*}\left(\mathrm{NO}^{+}\right)$transition) decreases, while absorption in the visible region (400 to $500 \mathrm{~nm}$ ) intensifies. Our group has suggested that the photochemical pathway followed by the polypyridyl nitrosyl ruthenium complexes under ultraviolet irradiation involves formation of the $\mathrm{Ru}-\mathrm{NO}^{0}$ species in aqueous solution. Due to the low affinity between $\mathrm{Ru}(\mathrm{II})$ and $\mathrm{NO}^{0}$, $\mathrm{NO}$ release takes place, and $\mathrm{Ru}^{\mathrm{II}}-\mathrm{H}_{2} \mathrm{O}$ arises as photoproduct $[55,75,76]$.

As in the case of the $\mathrm{NO}^{+/ 0}$ redox potential data, our results indicated that the series of polypyridyl ruthenium complex affords higher $\phi N O$ values during NO photorelease. This is consistent with the $\pi$-acceptor character of the ligand L (Table 2).

Table 2. Quantum yield ( $\phi N O)$ values for the nitrosyl polypyridine ruthenium complexes after flash photolysis at $355 \mathrm{~nm}$ and $\mathrm{pH}=2.01$ in trifluoroacetate buffer solution.

\begin{tabular}{|c|c|}
\hline Compounds & $\phi N O$ mol einstein ${ }^{-1}$ \\
\hline$c i s-\left[\mathrm{Ru}^{\mathrm{II}}(\mathrm{bpy})_{2}(\mathrm{NO}) \mathrm{Cl}\right]^{2+}$ & $0.98 *$ \\
\hline$c i s-\left[\mathrm{Ru}^{\mathrm{II}}(\mathrm{bpy})_{2}(\mathrm{py})(\mathrm{NO})\right]^{3+}$ & 0.16 \\
\hline$c i s-\left[\mathrm{Ru}{ }^{\mathrm{II}}(\mathrm{bpy})_{2}(4-\mathrm{pic})(\mathrm{NO}]^{3+}\right.$ & 0.17 \\
\hline$c i s-\left[\mathrm{Ru}^{\mathrm{II}}(\mathrm{bpy})_{2}(4-\mathrm{acpy})(\mathrm{NO})\right]^{3+}$ & 0.07 \\
\hline$\left[\mathrm{Ru}^{\mathrm{II}}(\mathrm{tpy})(\mathrm{bpy})(\mathrm{NO})\right]^{3+}$ & 0.14 \\
\hline$\left[\mathrm{Ru}^{\mathrm{II}}(\mathrm{tpy})(\mathrm{NH} . \mathrm{NHq})(\mathrm{NO})\right]^{3+}$ & 0.47 \\
\hline
\end{tabular}

$* \mathrm{pH}=5.7$ phosphate buffer solution.

The low chemical stability in physiological $\mathrm{pH}$ limits the pharmacological use of bipyridine ruthenium species. Therefore, we have hypothesized that it is possible to employ nitro ruthenium species as a source of NO. Apparently, by means of a different photochemical mechanism, cis$\left[\mathrm{Ru}(\mathrm{bpy})_{\mathrm{x}} \mathrm{L}\left(\mathrm{NO}_{2}\right)\right]^{\mathrm{n}+}$ is also photochemically reactive and produces NO under visible and ultraviolet light irradiation (Table 3) [77,78]. 
Table 3. Quantum yield ( $\phi N O)$ values of nitrosyl polypyridine ruthenium complexes after flash photolysis at $355 \mathrm{~nm}$ and $\mathrm{pH}=7.4$ in phosphate buffer solution.

\begin{tabular}{|c|c|}
\hline Compounds & $\phi N O$ mol eistein ${ }^{-1}$ \\
\hline$c i s-\left[\mathrm{Ru}^{\mathrm{II}}\left(\mathrm{NO}_{2}\right)(\text { bpy })_{2}(\text { py })\right]^{+}$ & 0.007 \\
\hline$c i s-\left[\mathrm{Ru}^{\mathrm{II}}\left(\mathrm{NO}_{2}\right)(\mathrm{bpy})_{2}(4-\mathrm{pic})\right]^{+}$ & 0.009 \\
\hline$c i s-\left[\mathrm{Ru}^{\mathrm{II}}\left(\mathrm{NO}_{2}\right)(\mathrm{bpy})_{2}(\mathrm{pz})\right]^{+}$ & 0.037 \\
\hline$\left[\mathrm{Ru}^{\mathrm{II}}\left(\mathrm{NO}_{2}\right)(\mathrm{tpy})(\mathrm{bpy})\right]^{+}$ & 0.036 \\
\hline
\end{tabular}

The maximum quantum yield measured for cis- $\left[\mathrm{Ru}(\mathrm{bpy})_{\mathrm{x}} \mathrm{L}\left(\mathrm{NO}_{2}\right)\right]^{\mathrm{n}+}$ is around $4 \%$. The suggested photochemical pathway involves homolytic cleavage of coordinated nitrite, to generate NO [77,78].

\subsubsection{RUNOCL}

cis-[RuCl(bpy $\left.)_{2}(\mathrm{NO})\right]\left(\mathrm{PF}_{6}\right)(\mathrm{RUNOCL})$ is a metal complex consisting of ruthenium and bypiridine ligands, bearing chloride and nitrosyl groups in the axial positions of ruthenium. The main chemical characteristic of this complex is its irradiation-dependent NO release. This represents a singular advantage regarding controlled NO release, because only irradiation stimulates this complex. Apart from being very important in the field of photodynamic therapy, NO release from this structure contributes to a better understanding of how NO affects the vascular tone during experimental studies. After NO release, the reaction mediated by light produces the aqua complex, which does not seem to be toxic to the VSMC at the applied concentration [43].

Using the specific probe for $\left[\mathrm{Ca}^{2+}\right]_{\mathrm{c}}$, fluo-3 acetoxymethyl ester (Fluo-3 AM), in the VSMC isolated from rat aorta, it is possible to verify that the RUNOCL complex diminishes $\left[\mathrm{Ca}^{2+}\right]_{\mathrm{c}}(60.0 \% \pm 10.0 \%$; $n=4)$ in relation to the control $(100 \%)$. The NO released from RUNOCL activates SGC sensitive to the selective inhibitor ODQ and $\mathrm{K}^{+}$channels sensitive to TEA, reducing the $\left[\mathrm{Ca}^{2+}\right]_{\mathrm{c}}$ in the VSMC to $81.0 \% \pm 5.0 \%(n=4)$ and $79.0 \% \pm 6.4 \%(n=4)$, respectively. In addition, the combination of ODQ and TEA abolishes the decreased $\left[\mathrm{Ca}^{2+}\right]_{\mathrm{c}}$ in the VSMC more effectively $(97.0 \% \pm 3.5 \% ; n=4)$. Taken together, these results suggest that the NO released from RUNOCL can activate $\mathrm{sGC}$ and $\mathrm{K}^{+}$channels, markedly lowering $\left[\mathrm{Ca}^{2+}\right]_{\mathrm{c}}[43]$.

Using the photo-induction technique and a visible light system with $\lambda>380 \mathrm{~nm}$, evaluation of the vasodilating effect induced by RUNOCL in rat aortic ring attests that RUNOCL elicits relaxation under light. The maximum effect is $101.2 \% \pm 3.7 \%$, with $\mathrm{pD}_{2}: 6.62 \pm 0.16(n=7)$. This effect does not happen in the absence of light irradiation [79]. At the maximum concentration, $1630 \mathrm{~s}$ is the time-course that is necessary to reach the maximum relaxation induced by RUNOCL [80]. The sGC inhibition with ODQ reduces the maximum relaxation and $\mathrm{pD}_{2}$ to $30.1 \% \pm 1.6 \%$ and to $6.35 \pm 0.05$, respectively $(n=4)$. Moreover, in the presence of light irradiation, RUNOCL increases the cGMP content in aortic tissue from $63.13 \pm 0.45 \mathrm{fmol} / \mu \mathrm{g}$ of protein to $70.56 \pm 4.64 \mathrm{fmol} / \mu \mathrm{g}$ of protein $(n=4)$. In the presence of $\mathrm{K}^{+}$channel blockers, TEA diminishes the potency of RUNOCL to $5.32 \pm 0.10(n=5)$, and iberiotoxin (large conductance $\mathrm{Ca}^{2+}$-dependent $\mathrm{K}^{+}$channel blocker) reduces its maximum effect to $60.7 \% \pm 3.4 \%(n=5)[79]$.

In summary, these studies have indicated that the NO released from RUNOCL exerts its vasodilating effect by $\mathrm{K}^{+}$channel activation via the cGMP-dependent pathway, which decreases 
$\left[\mathrm{Ca}^{2+}\right]_{\mathrm{c}}$ and induces vascular relaxation. On the basis of these results, Figure 6 illustrates the proposed mechanisms for the vasodilation induced by RUNOCL.

Figure 6. Proposed nitric oxide release and vasodilation mechanism elicited by cis$\left[\mathrm{RuCl}(\mathrm{bpy})_{2}(\mathrm{NO})\right]\left(\mathrm{PF}_{6}\right)(\mathrm{RUNOCL})$. The colored circles represent atoms in the chemical structure. The hydrogen atom has been omitted in the structure. Legend: $\mathrm{sGC}=$ soluble guanylyl cyclase, $\mathrm{GK}=\mathrm{G}$ Kinase Protein, $\mathrm{Ca}^{2+}=$ calcium, $\mathrm{K}^{+}=$potassium, $\left[\mathrm{Ca}^{2+}\right]_{\mathrm{c}}=$ cytosolic calcium concentration.

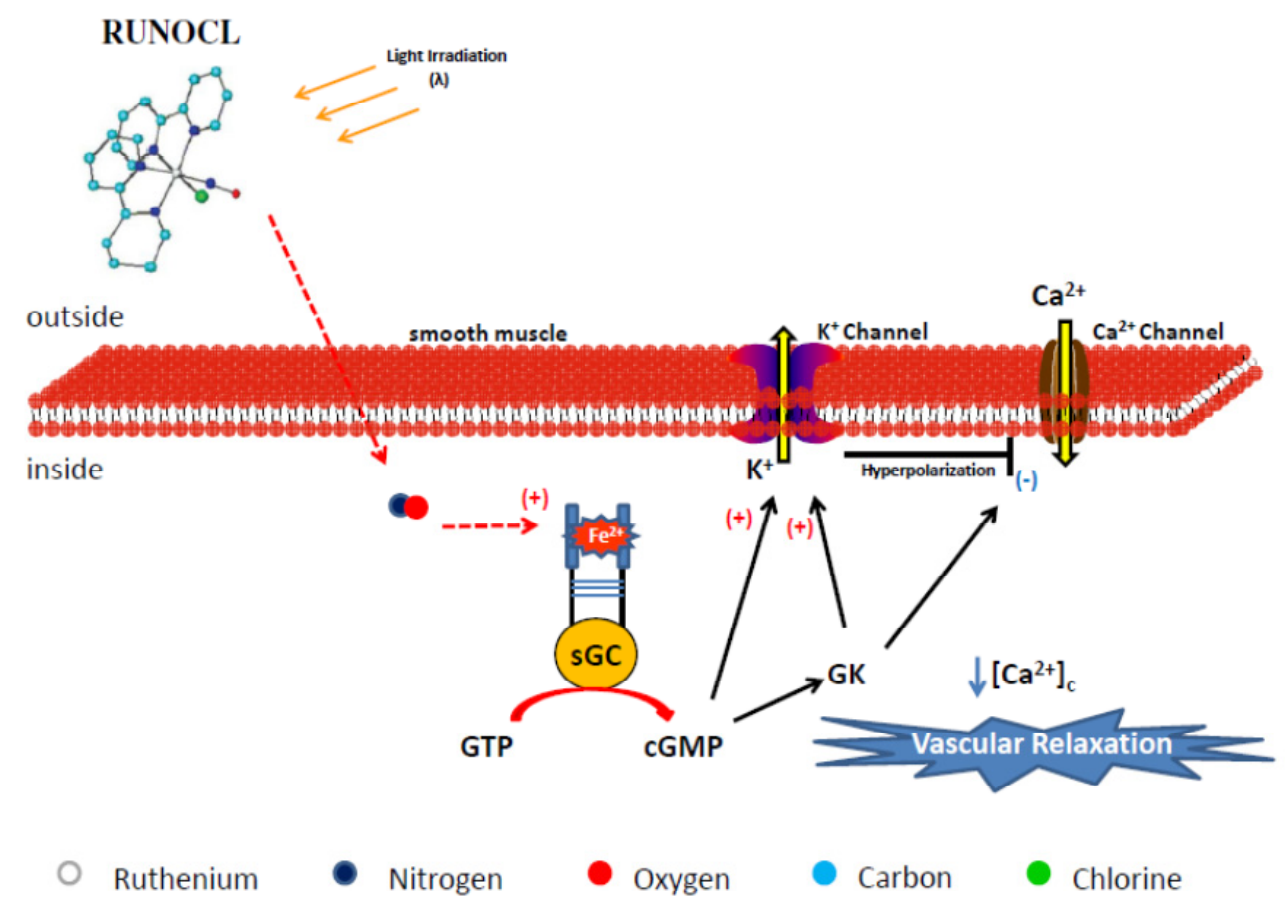

\subsubsection{RuBPY}

cis-[ $\left.\mathrm{RuNO}_{2}(\mathrm{bpy})_{2}(\mathrm{py})\right]\left(\mathrm{PF}_{6}\right)(\mathrm{RuBPY})$ is another metal complex that bears ruthenium, bypiridine ligands, and a nitrite group. The main chemical characteristic of this complex is its ability to release NO in the presence of the vascular tissue only. Basically, RuBPY differs from RUNOCL by the presence of nitrite $\left(\mathrm{NO}_{2}\right)$ rather than $\mathrm{NO}$ in the molecular structure. Using a fluorescence probe specific for NO, DAF-2DA, it is possible to observe that the cytosolic NO concentration $\left([\mathrm{NO}]_{\mathrm{c}}\right)$ in aortic slices increases significantly, as seen from the difference in the fluorescence intensity $(\Delta \mathrm{FI})$ after exposure to RuBPY ( $\Delta \mathrm{FI}: 1645.14 \pm 388.30 ; n=5)$. However, in the presence of ODQ, $\Delta \mathrm{FI}$ decreases to $366.88 \pm 120.3(n=7)$. Therefore, if we bear in mind that RuBPY only releases NO in the presence of rat aorta ring, it is possible to infer that the sGC-dependent mechanism converts $\mathrm{NO}_{2}$ from RuBPY to NO. The sGC inhibitor ODQ abolishes such $\mathrm{NO}_{2}$ conversion to $\mathrm{NO}$ [37].

As a pharmacological tool, ODQ oxidizes the sGC heme group, a potential center for $\mathrm{NO}_{2}$ reduction to NO. Researchers are extremely interested in $\mathrm{NO}_{2}$ conversion to $\mathrm{NO}$ [81]. $\mathrm{NO}$ originated from $\mathrm{NO}_{2}$ activates $\mathrm{sGC}$, raising the cGMP concentration and inducing vasodilation. The pharmacological potency of RuBPY is $6.54 \pm 0.07(n=5)$; the time-course is $240 \mathrm{~s}$. However, sGC 
inhibition by ODQ reduces the vasodilation induced by RuBPY from $104.4 \% \pm 1.1 \%$ to $38.0 \% \pm 3.6 \%(n=8)[37]$.

RuBPY releases radicalar NO species only. The $\mathrm{NO}^{0}$ released from RuBPY activates sGC, but it also seems to act directly on $\mathrm{K}^{+}$channels, to induce VSMC membrane hyperpolarization in a sGCindependent way [36]. This process apparently differs from that verified in the case of RUNOCL. In accordance with these findings, Figure 7 details the proposed mechanisms for the vasodilation induced by RuBPY.

Figure 7. Proposed nitric oxide release and vasodilation mechanism elicited by cis$\left[\mathrm{RuCl}(\text { bpy })_{2}\left(\right.\right.$ py) $\left.\mathrm{NO}_{2}\right]\left(\mathrm{PF}_{6}\right)(\mathrm{RuBPY})$. The colored circles represent atoms in the chemical structure. Legend: $\mathrm{sGC}=$ soluble guanylyl cyclase, $\mathrm{GK}=\mathrm{G}$ Kinase Protein, $\mathrm{Ca}^{2+}=$ calcium, $\mathrm{K}^{+}=$potassium, $\left[\mathrm{Ca}^{2+}\right]_{\mathrm{c}}=$ cytosolic calcium concentration.

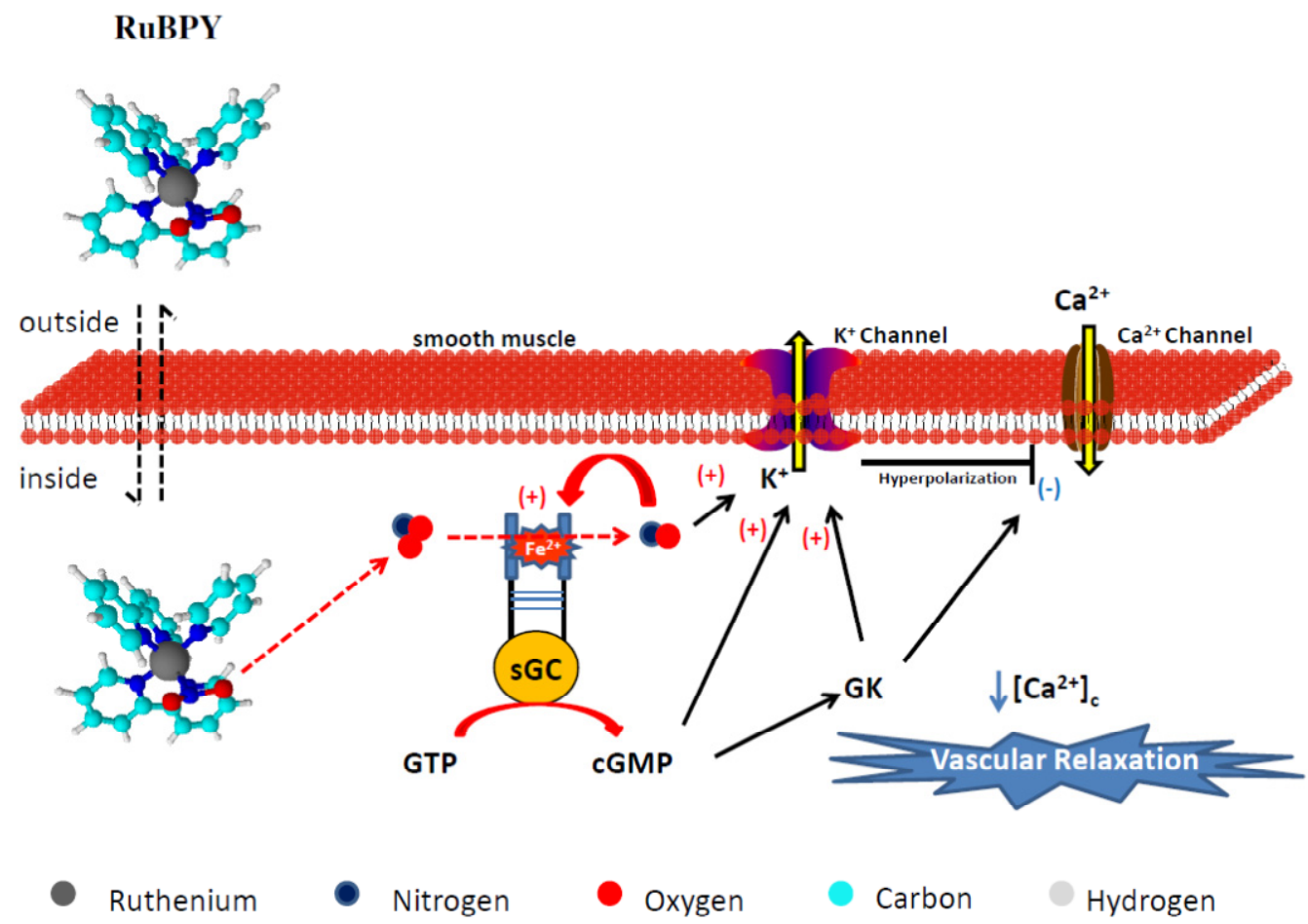

\subsubsection{Terpy ([Ru(tpy)(NH.NHq)NO $\left.]^{3+}\right)$}

The Terpy-induced vascular relaxation involves the release of both $\mathrm{NO}$ species, $\mathrm{NO}^{0}$ and $\mathrm{NO}^{-}$. It is important that NO released from the NO donors bind to $\mathrm{sGC}$, to modulate the activity of this enzyme and produce cGMP. $\mathrm{NO}^{0}$ is the main type of $\mathrm{NO}$ binding to the sGC heme moiety, which in turn activates G-kinase. Among other proteins, G-kinase can activate $\mathrm{K}^{+}$channels and/or SERCA.

The endogenous NO production by NO-synthase plays an important role in vascular tone control. sGC activation and cGMP production are believed to mediate this response. After that, NO is disposed in the form of inactive products such as nitrite and nitrate [82]. However, part of NO can modulate cell signaling by interacting with thiols and metals [83]. The distance from the point of synthesis or release and the cellular redox environment determine the biologically active concentration of NO [84]. Superoxide and subsequent peroxide production occur in many diseases such as hypertension [85]. In fact, hypertension is a multifactorial disease that involves many mechanisms including vascular 
endothelial dysfunction characterized by impaired NO bioavailability and increased reactive oxygen species production [17].

Impaired Terpy-induced relaxation occurs in renal hypertensive (2K-1C) rat aorta as compared with normotensive $(2 \mathrm{~K})$ rat aorta. The cytosolic $\mathrm{NO}$ concentration is lower in $2 \mathrm{~K}-1 \mathrm{C}$ than in $2 \mathrm{~K}$ rat aorta, whereas superoxide concentration is larger in $2 \mathrm{~K}-1 \mathrm{C}$ than in $2 \mathrm{~K}$ rat aorta. The antioxidant vitamin $\mathrm{C}$ improves the vasodilating effect induced by Terpy in renal hypertensive rat aorta [86].

Considering that resistance vessels are relevant for arterial pressure control, investigating the vascular relaxation induced by Terpy in mesenteric resistance artery from hypertensive and normotensive rats is an interesting matter. In fact, this could explain the differences between the effects that Terpy exerts in vivo and in vitro. In contrast to the results obtained in conductance vessels, Araujo et al. (2013) [87] have shown similar Terpy-induced relaxation in mesenteric resistance artery of renal hypertensive and normotensive rats. Confocal microscopy images have shown that Terpy releases similar amounts of NO in normotensive rat aorta and aorta from SHR.

To study the vascular relaxation induced by several ruthenium-derived complexes while avoiding interference of endogenous NO in the response, the experiments are usually performed in endotheliumdenuded artery. As reported by Bonaventura et al. [88], the complex Terpy can induce NO-synthase uncoupling and superoxide production.

\subsubsection{Vasodilating Effect in Normotensive and Hypertensive Rat Vessels}

Upon activation by NO released from Terpy, sGC can produce a large amount of cGMP. Interestingly, the levels of cGMP produced by NO released from Terpy are similar in aorta isolated from normotensive $(101.9 \% \pm 1.5 \%, n=5)$ and renal hypertensive rats $(101.8 \% \pm 2.0 \%, n=5)$ (Bonaventura et al., 2011). On the other hand, in normotensive sham-operated rats (2K), the relaxation is greater than that obtained in renal hypertensive $(2 \mathrm{~K}-1 \mathrm{C})$ rat aorta. In the case of SHR aorta, Munhoz et al. have demonstrated that the relaxation induced by TERPY is not different from that observed in normotensive rat aorta (control) [48]. The vascular relaxation partially depends on sGC activation in SHR aorta [48].

In mesenteric resistance artery, $2 \mathrm{~K}-1 \mathrm{C}$ and $2 \mathrm{~K}$ do not differ in terms of the Terpy-induced relaxation [87]. The protein expression of GCs subunits $\left(\alpha_{1}, \beta_{1}\right)$ is similar in renal hypertensive and normotensive mesenteric arteries. G-kinase activated by cGMP can phosphorylate sarcoplasmic reticulum $\mathrm{Ca}^{2+}$-ATPase, which stimulates cytosolic $\mathrm{Ca}^{2+}$ uptake into this organelle and consequent relaxation. Callera and Bendhack [89] have shown that the SERCA function remains unaltered in $2 \mathrm{~K}-1 \mathrm{C}$ rat aorta. In addition, $\mathrm{Ca}^{2+}$ uptake by SERCA does not seem to be involved in the Terpy-induced relaxation in $2 \mathrm{~K}$ and $2 \mathrm{~K}-1 \mathrm{C}$ rat aorta.

In the mesenteric artery, Terpy releases $\mathrm{NO}$ and activates cGMP-dependent protein reduction in $\mathrm{K}^{+}$ channels blockade and SERCA inhibition reduce in the same way during the relaxation induced by Terpy in $2 \mathrm{~K}-1 \mathrm{C}$ and $2 \mathrm{~K}$ mesenteric arteries [87]. However, SERCA inhibition in rat aorta does not inhibit the Terpy-induced relaxation [90].

NO produced by NO-synthase also acts as a vasodilator in cerebral arteries. Surprisingly, Terpy does not release NO in the cerebral rat basilar artery; it also fails to induce vascular relaxation in this 
artery [39]. In accordance with these findings, Figure 8 represents the partial mechanisms observed in each vessel for the vasodilation induced by Terpy.

Figure 8. Proposed nitric oxide release and vasodilation mechanism induced by Terpy $\left([\mathrm{Ru}(\mathrm{tpy})(\mathrm{NH} . \mathrm{NHq}) \mathrm{NO}]^{3+}\right)$. The colored circles represent atoms in the chemical structure. The hydrogen atom has been omitted in the structure. Legend: sGC = soluble guanylyl cyclase, $\mathrm{GK}=\mathrm{G}$ Kinase Protein, SERCA $=$ sarco/endoplasmic reticulum calcium-ATPase, $\mathrm{Ca}^{2+}=$ calcium, $\mathrm{K}^{+}=$potassium, $\left[\mathrm{Ca}^{2+}\right]_{\mathrm{c}}=$ cytosolic calcium concentration .

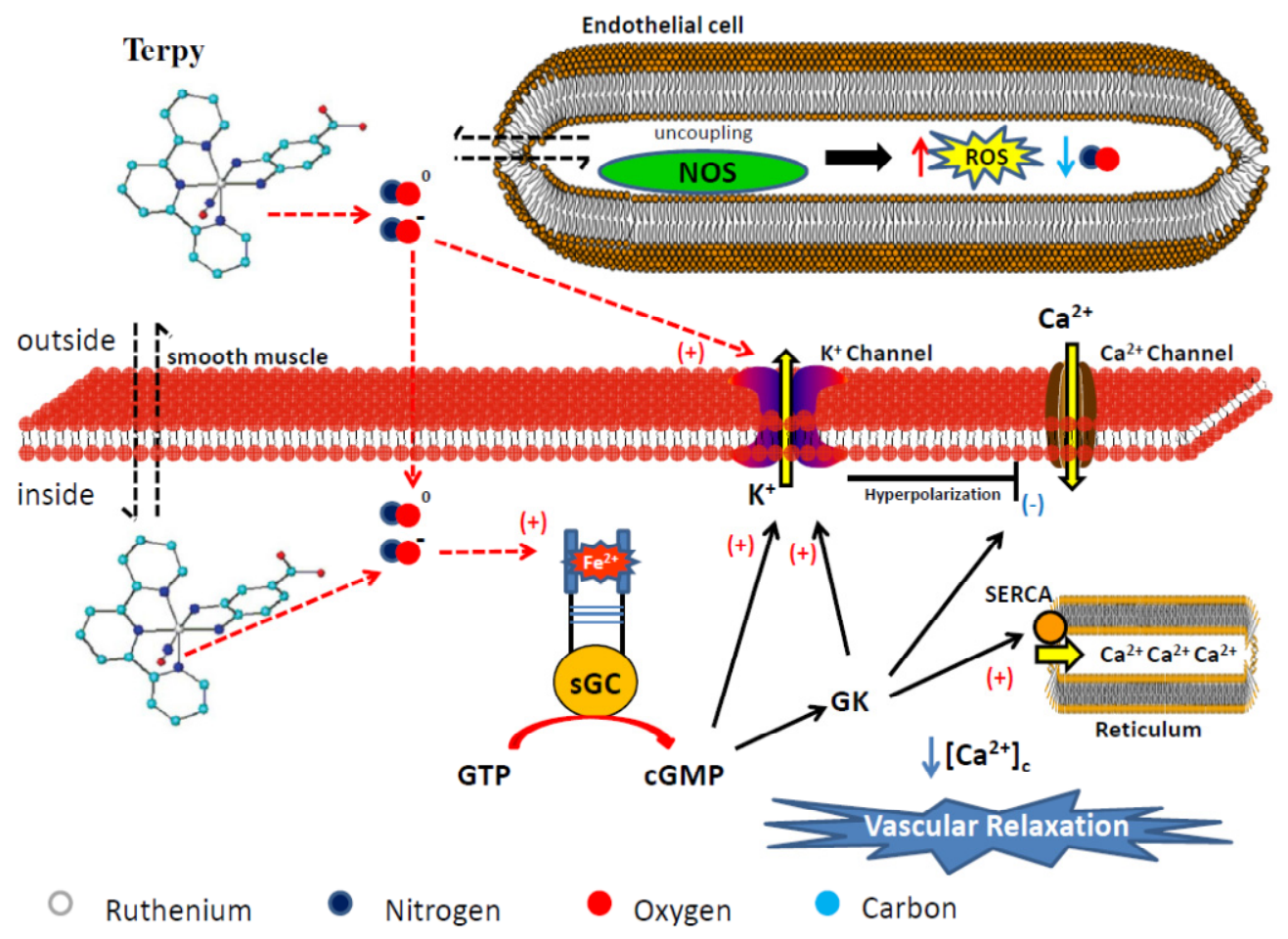

\subsubsection{Effects of Terpy on Arterial Pressure Control}

The mean arterial pressure depends directly on the vascular resistance and cardiac output. Despite the impaired vascular relaxation in $2 \mathrm{~K}-1 \mathrm{C}$ rat aorta, the hypotensive effect is greater in $2 \mathrm{~K}-1 \mathrm{C}$ than in $2 \mathrm{~K}$ rats. The complexes 15 ane and Terpy induce reduction in the mean arterial pressure in a dosedependent way in both $2 \mathrm{~K}-1 \mathrm{C}$ and $2 \mathrm{~K}$ rats ([65] and [34], respectively). Terpy also prompts a hypotensive effect in SHR, as shown by Munhoz et al. [48]. The hypotensive effect induced by Terpy is slow; it does not lead to reflex tachycardia in neither SHR nor normotensive rats. The Terpy-induced hypotensive effect is more potent in SHR than in normotensive Wistar rats. As compared with SNP, Terpy induces hypotension less potently [48].

Hypertension is a multifactorial disease that involves several organ systems. Increased reactive oxygen species have been described at its onset and during its progression [91]. Endothelial dysfunction plays a significant role in hypertension, due to the increased production of endotheliumderived contractile substances such as reactive oxygen species. 


\subsection{NO Production by Visible Light Irradiation of Nitrosyl Ruthenium Complex}

The possibility of using nitrosyl ruthenium complexes as NO delivery agents via photolysis has motivated us to design species that exhibit strong light absorption within the therapeutic window. To the best of our knowledge, the synthesized binuclear $\left[\mathrm{Ru}_{\mathrm{A}}(\mathrm{L})\left(\mathrm{NH}_{3}\right)_{4}(\mathrm{pz}) \mathrm{Ru}_{\mathrm{B}}(\mathrm{bpy})_{2} \mathrm{NO}\right]^{5+}(\mathrm{L}=$ amin, py, 4-pic and 4-acpy) constitutes the first example of a ruthenium complex with such property. The fragment $\left[\mathrm{Ru}_{\mathrm{A}}(\mathrm{L})\left(\mathrm{NH}_{3}\right)_{4}(\mathrm{pz})\right]$ works as an antenna: it absorbs light and photo-induces electron transfer to the second ruthenium fragment complex $\left[\mathrm{Ru}_{\mathrm{B}}(\mathrm{bpy})_{2} \mathrm{NO}\right]$. The final process culminates in $\mathrm{NO}$ production $[75,76]$. The excited state lifetime observed upon irradiation with wavelength of $532 \mathrm{~nm}$ is in the order of picoseconds, which should account for the low quantum yield observed during photolysis of $\left[\mathrm{Ru}_{\mathrm{A}}(\mathrm{L})\left(\mathrm{NH}_{3}\right)_{4}(\mathrm{pz}) \mathrm{Ru}_{\mathrm{B}}(\mathrm{bpy})_{2} \mathrm{NO}\right]^{5+}$. Binuclear complexes are a great concept on which to base the development of a coordination compound to serve as source of NO by photoinduced electron transfer. The synthesis of the compound [Ru(phthalocyanine) $\mathrm{NO}_{2} \mathrm{NO}$ ] (designated $\left[\mathrm{Ru}(\mathrm{NO})\left(\mathrm{NO}_{2}\right) \mathrm{pc}\right]$ [92]. hereafter, (Figure 9) is based on the same concept, and its photochemical and pharmacological properties have been described. Phthalocyanines have also proven to be efficient dyes for light absorption in the phototherapeutic window. Indeed, they constitute one of the secondgeneration photosensitizers used in photodynamic therapy (PDT) [92-95].

Figure 9. Chemical structure of the nitrosyl phthalocyanine ruthenium complex $\left[\mathrm{Ru}(\mathrm{NO})\left(\mathrm{NO}_{2}\right) \mathrm{pc}\right]$. The colored circles represent atoms in the chemical structure (cyan: carbon; blue: nitrogen; red: oxygen and gray: ruthenium).

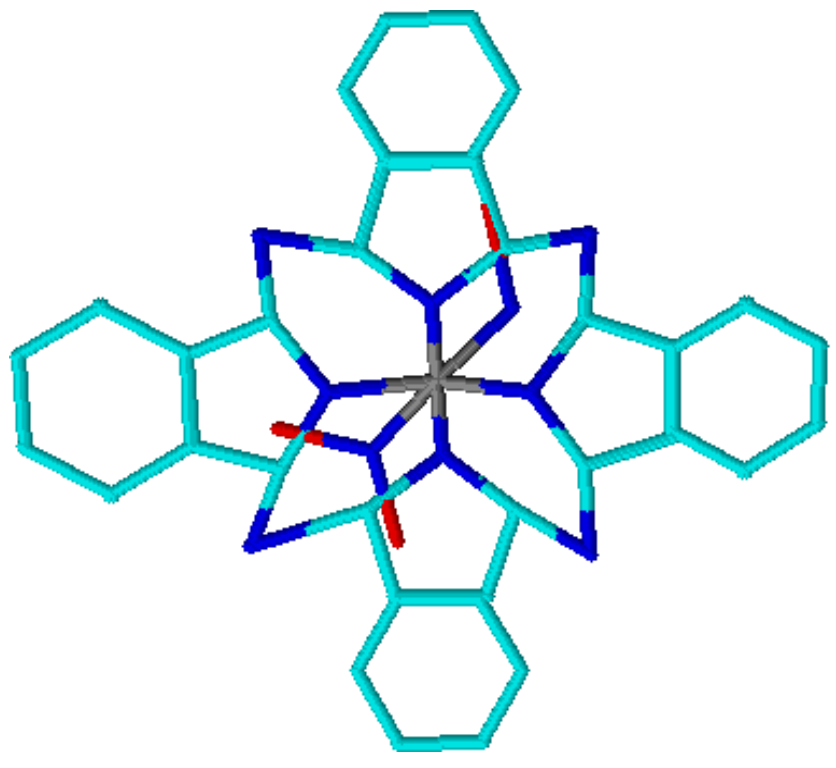

The $\left[\mathrm{Ru}(\mathrm{NO})\left(\mathrm{NO}_{2}\right) \mathrm{pc}\right]$ complex releases two NO molecules via a reduction process [78] or under irradiation with light at $670 \mathrm{~nm}$. Scheme 5 describes the overall mechanism. Photolysis revealed that $\left[\mathrm{Ru}(\mathrm{NO})\left(\mathrm{NO}_{2}\right) \mathrm{pc}\right]$ can also produce singlet oxygen, providing the opportunity to explore cytotoxicity aspects involving the synergism between NO and singlet oxygen [95]. Apparently, the biological mechanism involves reduction of the ruthenium species in the membrane, followed by NO release. We have proven this hypothesis from the vasodilation viewpoint. The $\left[\mathrm{Ru}(\mathrm{NO})\left(\mathrm{NO}_{2}\right) \mathrm{pc}\right]$ complex induces vascular relaxation in the same way as other ruthenium-based NO donor agents [95]. 
Scheme 5. Kinetic process related to the electron reduction of nitrosyl phthalocyanine ruthenium complex.

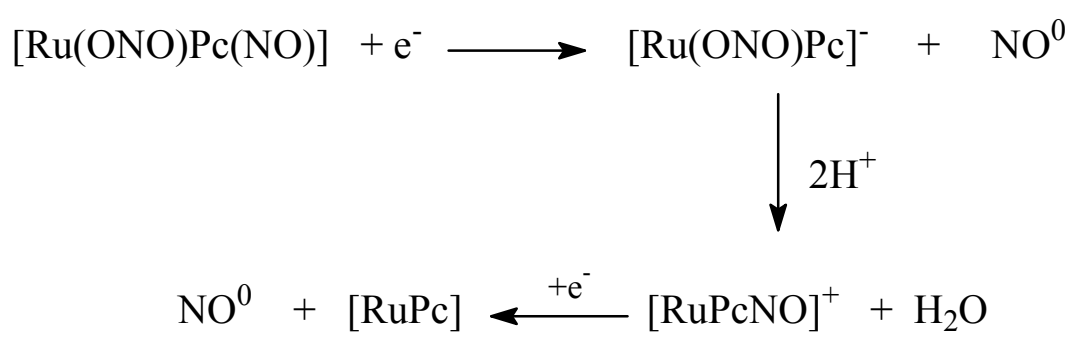

\section{General Aspects and Conclusions}

The time-course necessary to reach the maximum effect, the maximum effect per se, the pharmacological potency, and the action mechanisms of NO donors have been evaluated. These pharmacological parameters indicate that the molecular structure of the compounds to which NO is coordinated provides specific characteristics such as the reduction potential (chemical or tissuedependent) and excitation upon light irradiation, which can modulate the time (kinetic profile), the type, and the site of NO release. On the basis of our experience, employing ruthenium complexes with different molecular structures can contribute to achieving different pharmacological parameters as well as distinct final outcomes, although the NO is always the effector molecule underlying vasodilation. Over the years, these ruthenium-derived NO donor complexes have contributed to studying important vascular alterations in vessels of hypertensive rats such as $\mathrm{K}^{+}$channel functions [44,63], increased reactive oxygen species production [86], and loss of caveolae [96] that can impair the vasodilation induced by NO.

The description of these complexes and their characteristics as NO donors can contribute to a better understanding of the activation of the vascular nitrergic pathway in healthy and diseased tissues. It can also facilitate the selection of specific molecules as prototypes for the development of drugs with potential therapeutic application.

\section{Acknowledgements}

This work was supported by FAPESP (Fundação de Apoio a Pesquisa do Estado de São Paulo), CNPq/Brazil (Conselho Nacional de Desenvolvimento Científico e Tecnológico) and CAPES (Coordenação de Aperfeiçoamento de Pessoal de Nível Superior).

\section{Author Contributions}

R.G. de Lima: Participated in the design, writing, interpretation of the cited studies, and preparation of the chemical structure figures. B. R. Silva: Participated in the design, writing, interpretation of the cited studies, preparation of the cellular mechanisms figures, and review. R.S. da Silva: Participated in the writing, interpretation of the cited studies, preparation of the chemical schemes, and review. L.M. Bendhack: Participated in the design, writing, coordination of the proposal, interpretation of the cited studies, and review. 


\section{Conflicts of interest}

The authors declare that there are no conflicts of interest.

\section{References}

1. Radomski, M.W.; Palmer, R.M.J.; Moncada, S. The antiaggregating properties of vascular endothelium: Interactions between prostacyclin and nitric oxide. Br. J. Pharmacol. 1987, 92, 639-646.

2. Kline, D.D.; Yang, T.N.; Huang, P.L.; Prabhakar, N.R. Altered respiratory responses to hypoxia in mutant mice deficient in neuronal nitric oxide synthase. J. Physiol. 1998, 511, 273-287.

3. Bredt, D.S.; Hwang, P.M.; Snyder, S.H. Localization of nitric oxide synthase indicating a neural role for nitric oxide. Nature 1990, 347, 768-770.

4. Garthwaite, J. Neural nitric oxide signaling. Trends Neurosci. 1995, 18, 51-52.

5. Akesson, B.; Lundquist, I. Influence of nitric oxide modulators on cholinergically stimulated hormone release from mouse islets. J. Physiol. 1999, 515, 463-473.

6. Triyoso, D.H.; Good, T.A. Pulsatile shear stress leads to DNA fragmentation in human SH-SU5Y neuroblastoma cell line. J. Physiol. 1999, 515, 355-365.

7. Moncada, S.; Palmer, R.M.J.; Higgs, E.A. Nitric oxide: Physiology, pathophysiology and pharmacology. Pharmacol. Rev. 1991, 43, 109-42.

8. Furchgott, R.F.; Zawadzki, J.V. The obligatory role of endothelial cells and the relaxation of arterial smooth muscle by acetylcholine. Nature 1980, 288, 373-376.

9. Plane, F.; Wiley, K.E.; Jeremy, J.Y.; Cohen, R.A.; Garland, C.J. Evidence that different mechanisms underlie smooth muscle relaxation to nitric oxide and nitric oxide donors in the rabbit isolated carotid artery. Br. J. Pharmacol. 1998, 123, 1351-1358.

10. Van Hove, C.E.; van der Donckt, C.; Herman, A.G.; Bult, H.; Fransen, P. Vasodilator efficacy of nitric oxide depends on mechanisms of intracellular calcium mobilization in mouse aortic smooth muscle cells. Br. J. Pharmacol. 2009, 158, 920-930.

11. Palmer, R.M.; Ashton, D.S.; Moncada, S. Vascular endothelial cells synthesize nitric oxide from L-arginine. Nature 1988, 333, 664-666.

12. Rees, D.D.; Palmer, R.M.; Moncada, S. Role of endothelium derived nitric oxide in the regulation of blood pressure. Proc. Nat. Acad. Sci. USA 1989, 86, 3375-3378.

13. Stuehr, D.J.; Santolini, J.; Wang, Z.Q.; Wei, C.C.; Adak, S. Update on mechanism and catalytic regulation in the NO synthases. J. Biol. Chem. 2004, 279, 36167-36170.

14. Francis, S.H.; Busch, J.L.; Corbin, J.D. cGMP-dependent protein kinases and cGMP phosphodiesterases in nitric oxide and cGMP action. Pharmacol Rev. 2010, 62, 525-563.

15. Gao, Y. The multiple actions of NO. Pflug Arch. Eur. J Phy. 2010, 459, 829-839.

16. Hall, C.N.; Garthwaite, J. What is the real physiological NO concentration in vivo? Nitric Oxide 2009, 21, 92-103.

17. Silva, B.R.; Pernomian, L.; Bendhack, L.M. Contribution of oxidative stress to endothelial dysfunction in hypertension. Front. Physiol. 2012, 3, 441. 
18. Marsh,N.; Marsh, A. A short history of nitroglycerine and nitric oxide in pharmacology and physiology. Clin. Exp. Pharmacol. Physiol. 2000, 27, 313-319.

19. Gruetter, C.A.; Barry, B.K.; McNamara, D.B.; Gruetter, D.Y.; Kadowitz, P.J.; Ignarro, L. Relaxation of bovine coronary artery and activation of coronary arterial guanylate cyclase by nitric oxide, nitroprusside and a carcinogenic nitrosoamine. J. Cyclic. Nucleotide Res. 1979, 5, 211-224.

20. Ignarro, L.J.; Cirino, G.; Casini, A.; Napoli, C. Nitric oxide as a signaling molecule in the vascular system: An overview. J. Cardiovasc. Pharmacol. 1999, 34, 879-886.

21. Friederich, J.A.; Butterworth, J.F. Sodium nitroprusside: Twenty years and counting. Anesth. Analg. 1995, 81, 152-162.

22. Allardyce, C.S.; Dyson, P.J. Ruthenium in medicine: Current clinical uses and future prospects. Platin Met. Rev. 2001, 45, 62-69.

23. Marchesi, M.S.P.; Cicillini, S.A.; Prazias, A.C.L.; Bendhack, L.M.; Batista, A.A.; da Silva, R.S. Chemical mechanism of controlled nitric oxide release from trans-[RuCl([15]aneN $\left.{ }_{4}\right) \mathrm{NO}_{(}\left(\mathrm{PF}_{6}\right)_{2}$ as a vasorelaxant agent. Transit. Metal Chem. 2012, 37, 475-479.

24. Swayze, R.D.; Braun, A.P. Catalytically inactive mutant of type I cGMP-dependent protein kinase prevents enhancement of large conductance, calcium-sensitive $\mathrm{K}^{+}$channels by sodium nitroprusside and cGMP. J. Biol. Chem. 2001, 276, 19729-19737.

25. Lee, M.R.; Li, L.; Kitazawa, T. Cyclic GMP causes $\mathrm{Ca}^{2+}$ desensitization in vascular smooth muscle by activating the myosin light chain phosphatase. J. Biol. Chem. 1997, 272, 5063-5068.

26. Playfair, L. On the Nitroprussides, a new class of salts. Proc. R. Soc. London 1849, 139, 477-518.

27. Johnson, C.C. The actions and toxicity of sodium nitroprusside. Arch. Int. Pharmacodyn. Ther. 1929, 35, 489-496.

28. Moracca, P.P.; Bilte, E.M.; Hale, D.E.; Wasmuth, C.E.; Pontasse, E.F. Clinical evaluation of sodium nitroprusside as a hypotensive agent. Anesthesiology 1962, 23, 193-199.

29. Butler, A.R.; Megson, I.L. Non-heme iron nitrosyls in Biology.Chem. Rev. 2002, 102, 1155-1166.

30. Olabe, J.A. The coordination chemistry of nitrosyl in cyanoferrates. An exhibit of bioinorganic relevant reactions. Dalton Trans. 2008, 28, 3633-3648.

31. Bates, J.N.; Baker, M.T.; Guerra, R., Jr.; Harrison, D.G. Nitric oxide generation from nitroprusside by vascular tissue. Evidence that reduction of the nitroprusside anion and cianide loss are required. Biochem. Pharmacol. 1991, 42, S157-S165.

32. Harrison, D.G.; Bates, J.N. The nitrovasodilators. New ideas about old drugs. Circulation 1993, $87,1461-1467$.

33. Clarke, M.J.; Gaul, J.B. Chemistry relevant to the biological effects of nitric oxide and metallonitrosyls. Struct. Bonding 1993, 81, 147-181.

34. Rodrigues, G.J.; Pereira, A.C.; Vercesi, J.A.; Lima, R.G.; da Silva, R.S.; Bendhack, L.M. Long-lasting hypotensive effect in renal hypertensive rats induced by nitric oxide released from a ruthenium complex. J. Cardiovasc. Pharm. 2012, 60, 193-198.

35. Bonaventura, D.; Oliveira, F.S.; Togniolo, V.; Tedesco, A.C.; da Silva, R.S.; Bendhack, L.M. A macrocyclic nitrosyl ruthenium complex is a NO donor that induces rat aorta relaxation. Nitric Oxide 2004, 10, 83-91. 
36. Pereira, A.C.; Lunardi, C.N.; Paulo, M.; da Silva, R.S.; Bendhack, L.M. Nitric oxide generated by the compound RuBPY promotes the vascular smooth cell membrane hyperpolarization. Eur. J. Pharm. Sci. 2013, 48, 604-610.

37. Pereira, A.C.; Ford, P.C.; da Silva, R.S.; Bendhack, L.M. Ruthenium-nitrite complex as pro-drug releases NO in a tissue and enzyme-dependent way. Nitric Oxide 2011, 24, 192-198.

38. López-López, J.G.; Pérez-Viscaíno, F.; Cogolludo, A.L.; Ibarra, M.; Zaragozá-Arnáez, F.; Tamargo, J. Nitric oxide- and nitric oxide donors-induced relaxation and its modulation by oxidative stress in piglet pulmonary arteries. Br. J. Pharmacol. 2001, 133, 615-624.

39. Paulo, M.; Rodrigues, G.J.; da Silva, R.S.; Bendhack, L.M. A new NO donor failed to release NO and to induce relaxation in the rat basilar artery. Eur. J. Pharm. Sci. 2012, 45, 344-350.

40. Irvine, J.C.; Ritchie, R.H.; Favaloro, J.L.; Andrews, K.L.; Widdop, R.; Kemp-Harper, B.K. Nitroxyl (HNO): The cinderella of the nitric oxide story. Trends Pharmacol. Sci. 2008, 29, 601-608.

41. Favaloro, J.L.; Kemp-Harper, B.K. Redox variants of $\mathrm{NO}\left(\mathrm{NO}^{\circ}\right.$ and $\mathrm{HNO}$ ) elicit vasorelaxation of resistance arteries via distinct mechanisms. Am. J. Physiol. Heart Circ. Physiol. 2009, 296, H1274-H1280.

42. Bonaventura, D.; Oliveira, F.S.; Lunardi, C.N.; Vercesi, J.A.; da Silva, R.S.; Bendhack, L.M. Characterization of the mechanisms of action and nitric oxide species involved in the relaxation induced by the ruthenium complex. Nitric Oxide 2006, 15, 387-394.

43. Lunardi, C.N.; Cacciari, A.L.; da Silva, R.S.; Bendhack, L.M. Cytosolic calcium concentration is reduced by photolysis of a nitrosyl ruthenium complex in vascular smooth muscle cells. Nitric Oxide 2006, 15, 252-258.

44. Bonaventura, D.; de Lima, R.G.; da Silva, R.S.; Bendhack, L.M. NO donors-relaxation is impaired in aorta from hypertensive rats due to a reduced involvement of $\mathrm{K}^{+}$channels and sarcoplasmic reticulum $\mathrm{Ca}^{2+}$-ATPase. Life Sci. 2011, 89, 595-602.

45. Otsuka, Y.; DiPiero, A.; Hirt, E.; Brennaman, B.; Lockette, W. Vascular relaxation and cGMP in hypertension. Am. J. Physiol. 1988, 254, H163-H169.

46. Paulo, M.; Araujo, A.V.; Bendhack, L.M. Sodium nitroprusside activates potassium channels in the vena cava in normotensive but not in hypertensive rats. Hypertens Res. 2013, 36, 765-769.

47. Bonaventura, D.; Lunardi, C.N.; Rodrigues, G.J.; Neto, M.A.; Bendhack, L.M. A novel mechanism of vascular relaxation induced by sodium nitroprusside in the isolated rat aorta. Nitric Oxide 2008, 18, 287-295.

48. Munhoz, F.C.; Potje, S.R.; Pereira, A.C.; Daruge, M.G.; da Silva, R.S.; Bendhack, L.M.; Antoniali, C. Hypotensive and vasorelaxing effects of the new NO-donor [Ru(terpy)(bdq) $\left.\mathrm{NO}^{+}\right]^{3+}$ in spontaneously hypertensive rats. Nitric Oxide 2012, 26, 111-117.

49. Shaki, M.; Khanam, S.; Firdaus, F.; Latif, A.; Aatif, M.; Al-Resayes, S.I. Synthesis, spectroscopic characterization, DNA interaction and antibacterial study of metal complexes of tetraazamacrocyclic Schiff base. Spectrochim. Acta A 2012, 93, 354-362.

50. Tfouni, E.; Ferreira, K.Q.; Doro, F.G.; Takata, F.M.; da Silva, R.S.; da Rocha, Z.N. Ru(II) and $\mathrm{Ru}(\mathrm{III})$ complexes with cyclam and related species. Coord. Chem. Rev. 2005, 249, 405-418.

51. Ferreira, K.Q.; Lucchesi, A.M.; da Rocha, Z.N.; da Silva, R.S. Synthesis, characterization and kinetic studies of the $c i s-\left[\mathrm{RuCl}_{2} \text { (cyclen) }\right]^{+}$complex. Inorg. Chim. Acta 2002, 30, 147-151. 
52. Togniolo, V.; da Silva, R.S.; Tedesco, A.C. Photo-induced nitric oxide release from chlorobis(2,2'-bipyridine)nitrosylruthenium(II) in aqueous solution. Inorg. Chim. Acta 2001, 316, $7-12$.

53. Sauaia, M.G.; da Silva, R.S. The reactivity of nitrosyl ruthenium complexes containing polypyridyl ligands. Transit. Metal Chem. 2003, 28, 254-259.

54. Oliveira, F.S.; Togniolo, V.; Bonaventura, D.; Pupo, T.; Tedesco, A.C.; da Silva, R.S. Nitrosyl ruthenium complex as nitric oxide delivery agent: Synthesis, characterization and photochemical properties. Inorg. Chem. Comm. 2004, 7, 160-164.

55. De Lima, R.G.; Sauaia, M.G.; Bonaventura, D.; Tedesco, A.C.; Bendhack, L.M.; da Silva, R.S. Influence of ancillary ligand in the nitric oxide photo-release from the $\left[\mathrm{Ru}(\mathrm{L})(\text { terpy)NO}]^{3+}\right.$ and its vasodilator activity based on visible light irradiation. Inorg. Chim. Acta 2006, 359, 2543-2549.

56. Oliveira, F.S.; Ferreira, K.Q.; Bonaventura, D.; Bendhack, L.M.; Tedesco, A.C.; Machado, S.P.; Tfouni, E.; da Silva, R.S. The macrocyclic effect and vasodilation response based on the photoinduced nitric oxide release from trans- $[\mathrm{RuCl} \text { (tetraazamacrocycle) } \mathrm{NO}]^{2+}$. J. Inorg. Biochem. 2007, 161, 313-320.

57. Ferezin, C.Z.; Oliveira, F.S.; da Silva, R.S.; Simioni, A.R.; Tedesco, A.C.; Bendhack, L.M. The complex trans-[RuCl([15] $\left.\mathrm{aneN}_{4}\right) \mathrm{NO}^{2+}$ induces rat aorta relaxation by ultraviolet light irradiation. Nitric Oxide 2005, 13, 170-175.

58. Ceron, P.I.B.; Cremonez, D.C.; Bendhack, L.M.; Tedesco, A.C. The relaxation induced by S-nitroso-glutathione and S-nitroso-N-acetylcysteine in rat aorta is not related to nitric oxide production. J. Pharmacol. Exp. Ther. 2001, 298, 686-694.

59. Fricker, S.P.; Slade, E.; Powell, N.A.; Vaughan, O.J.; Henderson, G.R.; Murrer, B.A.; Megson, I.L.; Bisland, S.K.; Flitney, S.W. Ruthenium complexes as nitric oxide scavengers: A potential therapeutic approach to nitric oxidemediated diseases. Br. J. Pharmacol. 1997, 122, 1441-1449.

60. Hutchings, S.R.; Song, D.; Fricker, S.P.; Pang, C.C. The ruthenium-based nitric oxide scavenger, AMD6221, augments cardiovascular responsiveness to noradrenaline in rats with streptozotocininduced diabetes. Eur. J. Pharmacol. 2005, 528, 132-136.

61. Sguilla, F.S.; Tedesco, A.C.; Bendhack, L.M. A membrane potential-sensitive dye for vascular smooth muscle cells assays. Biochem. Biophys. Res. Commun. 2003, 301, 113-118.

62. Callera, G.E.; Varanda, W.A.; Bendhack, L.M. Impaired relaxation to acetylcholine in 2K-1C hypertensive rat aortas involves changes in membrane hyperpolarization instead of an abnormal contribution of endothelial factors. Gen. Pharmacol. 2000, 34, 379-389.

63. Bonaventura, D.; Oliveira, F.S.; da Silva, R.S.; Bendhack, L.M. Decreased vasodilation induced by a new nitric oxide donor in two kidney, one clip hypertensive rats is due to impaired $\mathrm{K}^{+}$ channel activation. Clin. Exp. Pharmacol. Physiol. 2005, 32, 478-481.

64. Marcondes, F.G.; Ferro, A.A.; Souza-Torsoni, A.; Sumitani, M.; Clarke, M.J.; Franco, D.W.; Tfouni, E.; Krieger, M.H. In vivo effects of the controlled NO donor/scavenger ruthenium cyclam complexes on blood pressure. Life Sci. 2002, 70, 2735-2752.

65. De Gaitani, C.M.; de Melo, M.C.C.; Lunardi, C.N.; de Oliveira, F.S.; da Silva, R.S.; Bendhack, L.M. Hypotensive effect of the nitrosyl ruthenium complex nitric oxide donor in renal hypertensive rats. Nitric Oxide 2009, 20, 195-199. 
66. Tfouni, E.; Krieger, M.H.; McGarvey, B.R.; Franco, D.W. Structure, chemical and photochemical reactivity and biological activity of some ruthenium amine nitrosyl complexes. Coord. Chem. Rev. 2003, 236, 57-69.

67. Suen, H.F.; Wilson, S.W.; Pomerantz, M.; Walsh, J.L. Photosubstitution reactions of terpyridine complexes of ruthenium(II). Inorg. Chem. 1989, 28, 786-791.

68. Caspar, A.; Meyer, T.J. Photochemistry of Ru(bpy $)_{3}{ }^{2+}$. Solvent effects. J. Am. Chem. Soc. 1983, $105,5583-5590$.

69. Johnson, E.C.; Sullivan, B.P.; Salmon, D.J.; Adeyemi, S.A.; Meyer, T.J. Synthesis and properties of the chloro-bridged dimer [(bpy)2RuCl] $22^{+}$and its transient $3^{+}$mixed-valence ion. Inorg. Chem. 1978, 17, 2211-2215.

70. Durham, B.; Wilson, S.R.; Hodgson, D.J.; Meyer, T.J. Cis-trans photoisomerization in $\mathrm{Ru}(\mathrm{bpy})_{2}\left(\mathrm{OH}_{2}\right)_{2}{ }^{2+}$. Crystal structure of trans- $\left[\mathrm{Ru}(\mathrm{bpy})_{2}\left(\mathrm{OH}_{2}\right)(\mathrm{OH})\right]\left(\mathrm{ClO}_{4}\right)_{2}$. J. Am. Chem. Soc. 1980, 102, 600-607.

71. Dovletoglou, A.; Adeyemi, S.A.; Meyer, T.J. Coordination and redox chemistry of substitutedpolypyridyl complexes of ruthenium. Org. Chem. 1996, 35, 4120-4127.

72. Hirano, T.; Ueda, T.; Mukaiad, M.; Nagao, H.; Oi, T. Reactions of $\left[\mathrm{RuCl}_{2} \mathrm{NOterpy}\right]^{+}$(terpy=2,2'6',2"-terpyridine) whit mono anions such as $\mathrm{NO}_{2}{ }^{-}, \mathrm{Br}^{-}$, and $\mathrm{N}_{3}{ }^{-}$and structural studies in terpy diruthenium having a nitrosyl ligand. J. Chem. Soc. Dalton Trans. 2001, 234, 1-4.

73. Nagao, H.; Nishimura, H.; Funato, H.; Ichikawa, Y.; Howell, F.S.; Mukaida M.; Kakihana, H. Synthesis, properties, and molecular-structure of trans-chloronitrosylbis(2,2'bipyridine)ruthenium $\left(2^{+}\right)$: Trans and cis isomer characteristics compared. Inorg. Chem.1989, 28, 3955-3959.

74. Godwin, J.B.; Meyer, T.J. Nitrosyl-nitrite interconversion in ruthenium complexes. Inorg. Chem. 1971, 24, 2150-2153.

75. Sauaia, M.G.; de Lima, R.G.; Tedesco, A.C.; da Silva, R.S. Photoinduced NO release by visible light irradiation from pyrazine-bridged nitrosyl ruthenium complexes. J. Am. Chem. Soc. 2003, $125,14718-14719$.

76. Sauaia, M.G.; Oliveira, F.S.; Tedesco, A.C.; da Silva, R.S. Control of NO release by light irradiation from nitrosyl-ruthenium complexes containing polypyridyl ligands. Inorg. Chim. Acta. 2003, 355, 191-196.

77. De Lima, R.G.; Sauaia M.G.; Bonaventura, D.; Tedesco, A.C.; Lopez, R.F.V.; Bendhack, L.M.; da Silva, R.S. Controlled nitric oxide photo-release from nitro ruthenium complexes: The vasodilator response produced by UV light irradiation. Inorg. Chim. Acta 2005, 358, 2643-2650.

78. Da Rocha, Z.N; de Lima, R.G.; Doro, F.G.; Tfouni, E.; da Silva, R.S. Photochemical production of nitric oxide from a nitrosyl phthalocyanine ruthenium complex by irradiation with light in the phototherapeutic window. Inorg. Chem. Comm. 2008, 11, 737-740.

79. Lunardi, C.N.; Vercesi, J.A.; da Silva, R.S.; Bendhack, L.M. Vasorelaxation induced by the new nitric oxide donor cis-[Ru(Cl)(bpy $\left.)_{2}(\mathrm{NO})\right]\left(\mathrm{PF}_{6}\right)$ is due to activation of $\mathrm{K}_{\mathrm{Ca}}$ by a cGMP-dependent pathway. Vasc. Pharmacol. 2007, 47, 139-144.

80. Lunardi, C.N.; da Silva, R.S.; Bendhack, L.M. New nitric oxide donors based on ruthenium complexes. Braz. J. Med. Biol. Res. 2009, 42, 87-93. 
81. Lundberg, J.O.; Weitzberg, E. Nitrite reduction to nitric oxide in the vasculature. Am. J. Physiol. Heart Circ. Physiol. 2008, 295, H477-H478.

82. Bryan, N.S.; Rassaf, T.; Maloney, R.E.; Rodriguez, C.M.; Saijo, F.; Rodriguez, J.R.; Feelisch, M. Cellular targets and mechanisms of nitros(yl)ation: An insight into their nature and kinetics in vivo. Proc. Natl. Acad. Sci. 2004, 101, 4308-4313.

83. Stamler, J.S.; Singel, D.J.; Loscalzo, J. Biochemistry of nitric oxide and its redox-activated forms. Science 1992, 258, 1898-1902.

84. Thomas, D.D.; Ridnour, L.A.; Isenberg, J.S.; Flores-Santana, W.; Switzer, C.H.; Donzelli, S.; Hussain, P.; Vecoli, C.; Paolocci, N.; Ambs, S.; et al. The chemical biology of nitric oxide: Implications in cellular signaling. Free Rad. Biol. Med. 2008, 45, 18-31.

85. Heitzer, T.; Wenzel, U.; Hink, U.; Krollner, D.; Skatchkov, M.; Stahl, R.A.K.; Macharzina, R.; Brase, J.H.; Meinertz, T.; Münzel, T. Increased NAD(P)H oxidase-mediated superoxide production in renovascular hypertension: Evidence for na involvement of protein kinase $\mathrm{C}$. Kidney Int. 1999, 55, 252-260.

86. Rodrigues, G.J.; Lunardi, C.N.; Lima, R.G.; Santos, C.X.; Laurindo, F.R.; da Silva, R.S.; Bendhack, L.M. Vitamin C improves the effect of a new nitric oxide donor on the vascular smooth muscle from renal hypertensive rats. Nitric Oxide 2008, 18, 176-183.

87. Araujo, A.V.; Pereira, A.C.; Grando, M.D.; da Silva, R.S.; Bendhack, L.M. The new NO donor Terpy induces similar relaxation in mesenteric resistance arteries of renal hypertensive and normotensive rats. Nitric Oxide 2013, 35, 47-53.

88. Bonaventura, D.; Lunardi, C.N.; Rodrigues, G.J.; Neto, M.A.; Vercesi, J.A.; de Lima, R.G.; da Silva, R.S.; Bendhack, L.M. Endothelium negatively modulates the vascular relaxation induced by nitric oxide donor, due to uncoupling NO synthase. J. Inorg. Biochem. 2009, 103, 1366-1374.

89. Callera, G.E.; Bendhack, L.M. Contribution of sarcoplasmic reticulum uptake and L-type calcium channels to altered vascular responsiveness in the aorta of renal hypertensive rats. Gen. Pharmacol. 1999, 33, 457-466.

90. Bonaventura, D.; de Lima, R.G.; Vercesi, J.A.; da Silva, R.S.; Bendhack, L.M. Comparison of the mechanisms underlying the relaxation induced by two nitric oxide donors: Sodium nitroprusside and a new ruthenium complex. Vasc. Pharmacol. 2007, 46, 215-222.

91. Montezano, A.C.; Touyz, R.M. Reactive oxygen species, vascular Noxs, and hypertension: Focus on translational and clinical research. Antioxid. Redox Sign. 2014, 20, 164-182.

92. Da Rocha, Z.N.; Marcehsi, M.S.P.; Molin, J.C.; Lunardi, C.N.; Miranda, K.; Bendhack, L.M.; da Silva, R.S. The induced NO-vasodilatation by chemical reduction of coordinated nitric íon cis$\left[\mathrm{Ru}\left(\mathrm{NO}_{2}\right)(\mathrm{L})(\text { bpy })_{2}\right]^{+}$complex. J. Chem. Soc. 2008, 32, 4282-4287.

93. Maranho, D.S.; de Lima, R.G.; Primo, F.L.; da Silva, R.S.; Tedesco, A.C. Photoinduced nitric oxide and singlet oxygen release from ZnPC liposome vehicle associated with the nitrosyl ruthenium complex: Synergistic effects in photodynamic therapy application. Photochem. Photobiol. 2009, 85, 705-713.

94. Allen, C.M.; Sharman, W.M.; van Lier, J.E. Current status of phthalocyanines in the photodynamic therapy of cancer. J. Porphyr. Phthalocyanines 2001, 5, 161-169. 
95. Carneiro, Z.A.; de Moraes, J.C.; Rodrigues, F.P.; de Lima, R.G.; Curti, C.; da Rocha, Z.N.; Paulo, M.; Bendhack, L.M.; Tedesco, A.C.; Formiga, A.L.; et al. Photocytotoxic activity of a nitrosyl phthalocyanine ruthenium complex - A system capable of producing nitric oxide and singlet oxygen. J. Inorg. Biochem. 2011, 105, 1035-1043.

96. Rodrigues, G.J.; Restini, C.B.; Lunardi, C.N.; Moreira, J.E.; Lima, R.G.; da Silva, R.S.; Bendhack, L.M. Caveolae dysfunction contributes to impaired relaxation induced by nitric oxide donor in aorta from renal hypertensive rats. J. Pharmacol. Exp. Ther. 2007, 323, 831-837.

(C) 2014 by the authors; licensee MDPI, Basel, Switzerland. This article is an open access article distributed under the terms and conditions of the Creative Commons Attribution license (http://creativecommons.org/licenses/by/3.0/). 